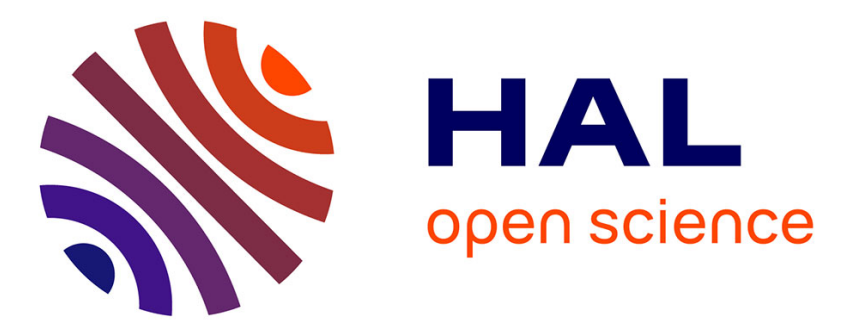

\title{
Analysis of system improvements in solar thermal and air source heat pump combisystems
}

Stefano Poppi, Chris Bales, Andreas Heinz, Franz Hengel, David Chèze, Igor

Mojic, Catia Cialani

\section{- To cite this version:}

Stefano Poppi, Chris Bales, Andreas Heinz, Franz Hengel, David Chèze, et al.. Analysis of system improvements in solar thermal and air source heat pump combisystems. Applied Energy, 2016, 173 (1), pp.606-623. 10.1016/j.apenergy.2016.04.048 . cea-01310230

\section{HAL Id: cea-01310230 https://hal-cea.archives-ouvertes.fr/cea-01310230}

Submitted on 2 May 2016

HAL is a multi-disciplinary open access archive for the deposit and dissemination of scientific research documents, whether they are published or not. The documents may come from teaching and research institutions in France or abroad, or from public or private research centers.
L'archive ouverte pluridisciplinaire HAL, est destinée au dépôt et à la diffusion de documents scientifiques de niveau recherche, publiés ou non, émanant des établissements d'enseignement et de recherche français ou étrangers, des laboratoires publics ou privés. 


\title{
Analysis of system improvements in solar thermal and air source heat pump combisystems.
}

\author{
Stefano Poppi*1,2, Chris Bales ${ }^{1}$, Andreas Heinz $^{4}$, Franz Hengel $^{4}$, David Chèze ${ }^{6}$, Igor Mojic $^{5}$, \\ Catia Cialani ${ }^{3}$ \\ ${ }^{1}$ Solar Energy Research Center (SERC), Dalarna University College, S-79188 Falun, Sweden \\ ${ }^{2}$ Department of Energy Technology, KTH, SE-100 44 Stockholm, Sweden \\ ${ }^{3}$ Department of Economics, Dalarna University College, S-79188 Falun, Sweden \\ ${ }^{4}$ Institute of Thermal Engineering, Graz University of Technology, Inffeldgasse 25b, A-8010 Graz, Austria \\ ${ }^{5}$ Institut für Solartechnik SPF, University of Applied Sciences HSR, Oberseestr. 10, 8640 Rapperswil, Switzerland \\ ${ }^{6}$ CEA, LITEN, Department of Solar Technologies, F-73375 Le Bourget du Lac, France
}

*Corresponding author. Tel.: +46 2377 87 46; Fax: +4623778701; E-mail address: spo@du.se

This is an author-produced version of a paper accepted for publication in the Applied Energy journal (Elsevier) in April 2016. This version has been peer-reviewed, but does not include the final publisher proof corrections, published layout, or pagination.

For the official version, please refer to doi:10.1016/i.apenergy.2016.04.048

\begin{abstract}
A solar thermal and heat pump combisystem is one of many system alternatives on the market for supplying domestic hot water (DHW) and space heating (SH) in dwellings. In this study a reference solar thermal and air source heat pump combisystem was defined and modelled based on products available on the market. Based on the results of an extensive literature survey, several system variations were investigated to show the influence of heat pump cycle, thermal storage and system integration on the use of electricity for two houses in the climates of Zurich and Carcassonne. A singular economic cash flow analysis was carried out and the "additional investment limit" of each system variation was determined for a range of economic boundary conditions. This is the maximum extra investment cost for the system variant compared to the reference system that will give a break even result for a 10 year period. The results shows that variations in electricity price affects the additional investment limit far more than the other economic parameters. Several of the variants show potential for achieving a cost benefit, but the potential varies a lot depending on load and climate boundary conditions. For all variants, the biggest difference in electricity savings was found for Zurich rather than in Carcassonne, which is explained by the larger heating load. However, in three cases the largest savings were for the SFH45 house despite the fact that the annual electricity use of the system is much lower than that for the SFH100 house, 3581
\end{abstract}


$\mathrm{kWh}$ /year compared to $8340 \mathrm{kWh} / \mathrm{year}$. This was attributed to the fact that, in these cases, the operating level of the space heating circuit played a significant role, the SFH45 house being supplied with a 35/30 ${ }^{\circ} \mathrm{C}$ heating system while the SFH100 was supplied with a $55 / 45^{\circ} \mathrm{C}$ heating system.

\title{
Keywords
}

Solar combisystem, heat pump cycle, thermal storage, hydraulics

\section{Nomenclature}

\author{
AN Annuity [€/year] \\ ASHP Air Source Heat Pump \\ AC45 ASHP, house with insulation standard SFH45 and with Carcassonne climate \\ AC100 ASHP, house with insulation standard SFH100 and with Carcassonne climate \\ AZ45 ASHP, house with insulation standard SFH45 and with Zurich climate \\ AZ100 ASHP, house with insulation standard SFH100 and Zurich climate \\ C Electricity cost [€/year] \\ CS Constant speed \\ Cost Annual cash flow [€/year] \\ CA Carcassonne \\ COP Coefficient of Performance \\ DHW Domestic Hot Water \\ FSC Fractional Solar Consumption \\ GSHP Ground source heat pump \\ GC45 GSHP, house with insulation standard SFH45 and with Carcassonne climate \\ GC100 GSHP, house with insulation standard SFH100 and with Carcassonne climate \\ GZ45 GSHP, house with insulation standard SFH45 and with Zurich climate \\ GZ100 GSHP, house with insulation standard SFH100 and Zurich climate \\ I Annual solar radiation [kWh/year]
}




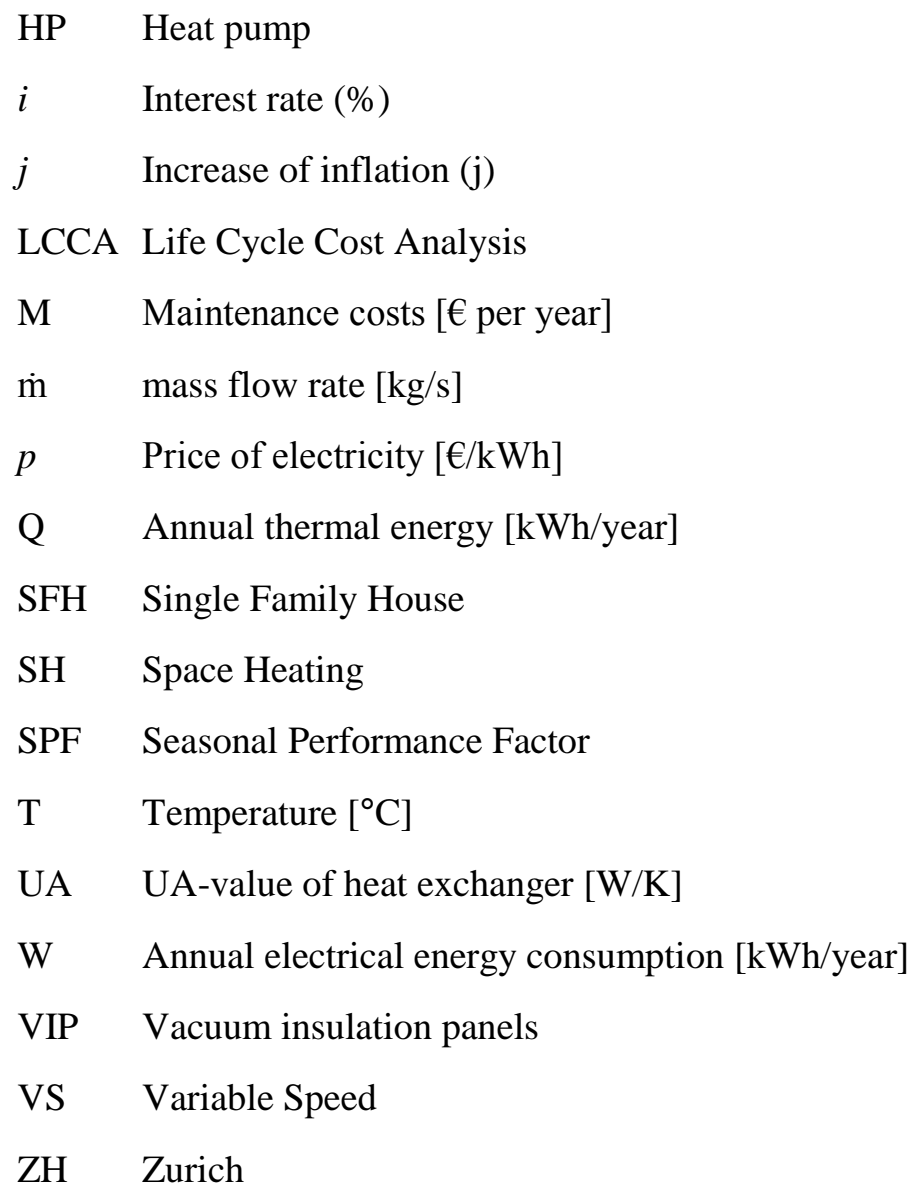

$\begin{array}{ll}\text { Subscript } & \\ \text { BOTTOM } & \text { bottom of the storage tank } \\ \text { Corr } & \text { corrected } \\ \text { Ctr } & \text { controller } \\ \text { cpr } & \text { compressor } \\ \text { DHW } & \text { domestic hot water } \\ \text { dist } & \text { circulation pumps } \\ \text { EH } & \text { auxiliary electrical heater } \\ \text { el } & \text { electrical } \\ \text { int } & \text { in the store } \\ \text { HP } & \text { heat pump } \\ \text { LOSS } & \text { losses } \\ n & \text { year } \\ \text { pen } & \text { penalties }\end{array}$




$\begin{array}{ll}\text { S } & \text { South } \\ \text { SC } & \text { solar collector } \\ \text { SH } & \text { space heating } \\ \text { SHP } & \text { solar heat pump } \\ \text { SIDE } & \text { side of the storage tank } \\ \text { Start/stop } & \text { heat pump start and stop } \\ \text { TOP } & \text { top of the storage tank } \\ \text { tot } & \text { total } \\ \text { V } & \text { system variation } \\ 45 & \text { tilt angle of solar collector }\end{array}$

\section{Introduction}

The use of solar thermal and heat pump combisystems is widespread in the market of space heating (SH) and hot water preparation (DHW) for single family houses. Recent studies of the state of art in Europe [1, 2] have shown that the solar collector can be used either in parallel or in series with a heat pump, but the configuration in parallel is preferable when radiation is high enough as it is more energetically efficient [3].

Air source heat pumps (ASHP) are widely used due to their easy installation and the comparatively low price, combined with an efficiency that has been improved over recent years ([4]). To improve costeffectiveness, the system can either be improved in terms of performance at the same time as the costs increase by a relatively small amount, or alternatively the system cost can be reduced as long as the system performance is reduced by a relatively small amount. A literature study of advances in the field of heat pump cycle, thermal storage and system integration was carried out. Much of the literature was in the context of heat pump only or solar combisystems with gas or other auxiliary, but not in the context of a solar assisted air source heat pump system. Based on the survey, several advances were chosen to investigate further with a reference solar combisystem with ASHP for two climates and two building loads so that they could be compared with one another for a range of boundary conditions. These were: vapour injection cycle, speed controlled compressor, four/three pipe connection, a four-way valve in the space heating circuit, vacuum insulation panels on the storage tank as well as integration of the heat pump 
condenser in the store. The relevant literature for these is presented in the following paragraphs. The whole literature survey is not included due to lack of space.

ASHP have a poor COP combined with a reduced heating capacity at low evaporation temperature, for instance in a cold climate. Moreover, when the heat pump delivers heat at high temperature, e.g. for DHW purposes, the compressor discharge temperature increases dramatically due to the low suction pressure and high pressure ratio across the compressor. By injecting vapour refrigerant into the compressor at an intermediate pressure, the discharge temperature is decreased and both the heating capacity and the COP are increased significantly. Injection cycles are possible with a flash tank or with an economizer; in the case with a flash tank, the separation between the liquid phase and the vapour phase of refrigerant occurs in a tank whereas in the case with an economizer a plate heat exchanger is used to vaporize the two phase refrigerant. Several studies on heat pumps with vapour injection have been recently published [5-10]. Wang et al. [5] proposed a variation to the flash tank cycle that uses a two-phase ejector to recover part of energy losses due to the refrigerant expansion process. Wang et al. compared performances of the twophase ejector cycle to those of the flash tank cycle and showed that the cycle COP improved by using a two-phase ejector, but percentage differences were small. Baek et al. [6] investigated the effects of several injection techniques on heating performances of a heat pump that works with carbon dioxide and operates at low ambient temperatures. Results for the best case scenario showed improvements of $18.3 \%$ and $9.4 \%$ in heating capacity and COP, respectively, compared to the case with a non-injection cycle under the same given conditions. Redon et al. [7] did an analysis and optimization of two heat pump systems, one with a flash tank and one with an economizer, and with different refrigerants. Redon et al. showed that flash tank systems are preferable as they enable the heat pump to work close to the optimum COP and with a lower discharge temperature than in economizer systems. However, it was shown that COP is strongly affected by the amount of refrigerant superheat at the injection port and thus to have an accurate control of the degree of superheating becomes crucial.

The heating capacity of ASHP increases with an increasing ambient air temperature which coincides with decreasing heating demand when installed in residential applications. Consequently, the heat pump capacity is larger than the heat demand for long periods causing many heat pump starts and stops. By controlling the speed of the compressor, the heating capacity of ASHP can be adapted closer to the heating load and therefore the number of heat pump starts and stops is reduced, leading to a longer compressor life. Many studies on capacity controlled heat pumps are available in the literature [11-18], of which a few include a comparison of systems with variable speed (VS) compressors to systems with constant speed (CS) compressors [13,15,18]. Mader and Madani [13] quantified system costs of capacity controlled ASHP for three climate zones and showed that the use of systems with VS compressor is not always cost- 
effective, but is profitable in a colder climate. Madani et al. in $[14,15]$ simulated ground source heat pump (GSHP) systems with VS compressors and showed that was no difference in SPF in the case with a CS compressor that was sized to cover more than $65 \%$ of the peak heat demand. Karlsson and Fahlén [18] investigated systems with GSHP and showed that despite the fact that VS compressors improve COP at partial loads, system performances do not differ significantly compared to CS compressors due to lower efficiency of VS compressor, and the efficiency and control of the circulation pumps of the borehole system and of the heating system.

The heart of solar thermal combisystems is the storage tank and by improving the thermal gradient, so called storage stratification, system performances may be enhanced considerably ([19-26]). Andersen et al. [21,23] and Davidson and Adams [26] investigated thermal performances of storage tanks that had different configurations of charging devices. These devices, called stratifiers, build stratification by directing the inlet flow to the height of the tank where the temperature is close to the temperature of the inlet fluid. Andersen et al. studied multilayer fabric pipes in [21] and a rigid stratifier with openings covered by flaps in [23]. Results showed that better storage stratification occurred in the case with a two layer fabric stratifier with a distance of $10 \mathrm{~mm}$ between each fabric layer instead of using one fabric layer. In the case with a rigid stratifier, better results were achieved if the flow in the lower openings was physically prevented being sucked into the pipe from the lower flap at the beginning of the measurement. Davidson and Adams in [26] compared several fabric manifolds with a conventional inlet pipe. They concluded that the fabric manifold is significantly more effective than the conventional drop-tube inlet. Furbo et al. [22] studied stratification enhanced by discharge and showed 5\% increase in thermal performance of a solar combisystem by using two draw-off levels for DHW preparation instead of one draw-off level and by using two draw-off levels for the heating system instead of one draw-off. Knudsen and Furbo [24] investigated thermal stratification in two small solar domestic hot water systems with mantle heat exchangers that had different height for the mantle inlet ports. The system with lower inlet height had better thermal performance than the system with higher inlet height, however relative difference were small. Bales and Persson [25] studied several solutions with external heat exchangers for DHW preparation and showed that the system performance improved significantly with units that had low return temperatures to the tank. All these studies showed potential for improving system performances by improving storage stratification, but relative improvements were dependent on system design and operation as well as the solar fraction.

These kinds of solutions lead to improved system performances, but system costs may increase considerably and thus may not always be cost-effective. Storage stratification can also be enhanced by using an optimized hydraulic layout as shown in [27-30]. Glembin and Rockendorf [27] and Lorenz et al. [30] simulated the use of a four-way valve that takes the fluid either from the top of the tank or from 
below the zone heated by the auxiliary heater, so as to favor the use of water heated by solar and showed that the systems reduced the final energy demand by $1.3 \%$ to $7 \%$. Haller et al. [31] and Poppi and Bales [32] simulated solutions in hydraulics and control that lead to important energy savings in solar thermal and heat pump combisystems. Poppi and Bales showed that the hydraulic configuration of "four pipe connection" minimizes the volume of storage tank that is heated by the heat pump for DHW charging. This study were for fixed boundary conditions with space heating temperatures for floor heating. It is not clear whether these results are valid for other boundary conditions, especially for higher space heating temperature where the difference to DHW charge temperature is lower and the effect could be expected to be smaller. Haller et al. studied a similar system and showed that position of the DHW temperature sensor influences the number of heat pump starts and thereby also system performance. They recommend placing the temperature sensor at a safe distance above the space heating zone of the tank, at least $20 \mathrm{~cm}$.

Tank heat losses cause a reduction in heat available in the thermal storage, especially in the upper volume of the tank, and thus lead to more use of the heat pump. Vacuum insulation panels (VIP) have a thermal conductance that is roughly $10 \%$ of standard insulation materials used for tanks. Hence, a drastic reduction of heat losses is possible with the use of VIP [33,34]. VIP insulation is not used in many commercial heating systems due to its relatively high cost, but as the price of VIP has reduced considerably over the last years, it is interesting to determine for what cost it is cost-effective compared to traditional insulation technologies.

The integration of heat pump condenser into the storage tank favours system compactness and has the potential to reduce costs considerably. On the other hand, systems with immersed condensers have poor storage stratification, as shown in experiments carried out by Fernández-Seara et al. in [35], and thus can lead to non-optimal system performance. Immersed condenser heat exchangers are often configured as helical coiled tubes [35-39] that cover either part of the tank [35] or the whole tank [37]. Sizing recommendations are given by Guo et al. in [37] in terms of ratio of the condenser area to the evaporator area. Zhang et al. in [39] did a system optimization by focusing on the refrigerant charge, on the length of the immersed condenser pipe and on the matching of heat pump capacity with the tank size. The main conclusion was that system performances improved by doing so.

In recent studies on solar combisystems [40-42] the solar fraction [41] and the energy savings [40,42] were mainly used as key-figures for system comparison. When comparing systems with such key figures, it is important to ensure that the systems provide the same level of comfort, thus same standard to the user. One method for ensuring this is the concept of penalty functions, which was introduced within the IEA SHC Task26 programme, and is reported in [43]. If the investigated heating system is not able to fulfil the user demand for the room temperature or DHW supply temperature, an additional energy demand, the 
penalty, is calculated and included as an auxiliary energy demand of the heating system [43]. None of the recent aforementioned studies included the penalties in the definition of annual energy demand and SPF, although others, less rigorous approaches, have been used to ensure the same level of energy supply to the user.

Life Cycle Cost Analysis (LCCA) [44] has been used in studies on solar combisystems [45-49] to assess cost-effectiveness. In the LCCA, total costs of ownership are used as a key figure for the economic comparison, which takes into account all costs of acquiring, owning, and disposing of a building or building system [44]. Colclough and Griffiths [45] analysed the financial viability of the application of a solar combisystem with seasonal energy store serving a $215 \mathrm{~m}^{2}$ passive house in a temperate maritime climate. The analysis showed financial savings compared with the use of electric heating given the timeframes consistent with the service life of the seasonal energy store. Chaturvedi et al. [46] used LCCA to assess the economic feasibility of direct expansion solar assisted heat pump systems for low temperature water heating applications. Authors concluded that these systems are both economical as well as energy conserving solutions compared to the electric-only hot water heaters. Hin et al. $[47,48]$ and Leckner and Zmeureanu [49] investigated solar combisystem in energy efficient houses in Montreal. The optimizations performed by Hin et al. were able to reduce significantly the life cycle costs of the combisystem compared to those of the base case scenario. However, none of the optimal configurations had acceptable financial payback periods due to the high cost of the solar collector technologies and the low price of electricity. Leckner and Zmeureanu concluded that the price of electricity needs to be $\$ 0.24 / \mathrm{kWh}$ for a 40 year payback and $\$ 0.32 / \mathrm{kWh}$ for a 25 year payback to make the solar combisystem cost-effective.

The scope of this study is on advanced technologies in the field of renewable energy for domestic applications based on solar thermal and heat pump technology for space heating and hot water preparation. In the study, where solutions not fully available on the market are investigated, costs were difficult to determine. Thus, an alternative variant of the LCCA was used that derives investment costs that satisfy given cost effectiveness criteria, rather than using known investment costs to determine profitability. A singular economic cash flow model based on cost-effectiveness was developed to compare the maximum allowed extra investment cost, between a system variation and a reference, in order to have a payback time of 10 years. This has been termed the "additional investment limit". A sensitivity analysis was carried out to show the impact of the main assumptions for economic parameters on this additional investment limit as well as to verify the consistency and the robustness of the economic model.

The authors found that despite the extensive literature on the topic, there is little relevant literature with economic calculations and none that allows the reader to compare alternative system improvements for the 
same boundary conditions and with the same level of comfort to the end user. Therefore, the aim of this study was to fill this gap by comparing the performance and cost-effectiveness of a number of promising improvements to solar combisystems with ASHP as backup heater for a range of boundary conditions in terms of climate and load. In order to do this, a new approach was developed to determine how much an improvement can cost for it to be cost-effective for given economic and system boundary conditions. Penalty functions were used to ensure that all variations provided the same comfort requirements.

This investigation has been carried out within the frame of the European Union's Seventh Framework Program FP7/2007-2011 in a project called MacSheep [50].

\section{Methodology}

This study was carried out in Trnsys17 [51] for two climates, Zurich (ZH) and Carcassonne (CA), as well as two houses with different insulation standards (SFH45 and SFH100) in order to get a large range of space heating loads as well as solar resource. The fractional solar consumption (FSC) is the ratio of the usable irradiation available on the collector field to the useful heat delivered [43], calculated for a complete year, with values being between 0 and 1 . It has been shown to be correlated with the fractional energy savings of solar combisystems in general [43] as well as solar combisystems with heat pumps [52]. The FSC for the combination of the chosen two climates and two house standards ranged from 0.33 to 0.76. Additionally, the heat distribution systems for the two houses were different, with the SFH45 house having design temperatures representing floor heating while for the SFH100 house design temperatures were for radiators and were thus higher. The model parameters for the building models were the same as those defined for IEA SHC Task 44 / HPP Annex 38 (T44A38) "Solar and Heat Pump Systems" and shown in [53]. The buildings have a total inside façade area of $203 \mathrm{~m}^{2}$ and a total window area of $23 \mathrm{~m}^{2}$. Different wall thicknesses were applied for deriving the two house standards. The UA-values of buildings are 168 and $290 \mathrm{~W} / \mathrm{K}$ for the SFH45 and SFH100 respectively. Climate data are shown in Table 1. The average ambient temperature is $4{ }^{\circ} \mathrm{C}$ higher in Carcassonne than Zurich and the design outside ambient temperature is $5{ }^{\circ} \mathrm{C}$ higher. This results in $13 \%$ higher design space heating load in Zurich for the SFH45 house (refer to Table 2), determined based on a steady state calculation at the design ambient temperature with no passive solar gains to the building. The radiation on the $45^{\circ}$ inclined south facing surface is also $255 \mathrm{kWh} /(\mathrm{m} 2$-year) higher in Carcassonne. The heating degree days (HDD) are a summation of the difference between the outdoor temperature and a specified base temperature $\left(\mathrm{T}_{\text {base }}\right)$ over a year [54]. It has shown that $\mathrm{HDD}_{15}$ ranges from 500 on the Mediterranean coast to 4000 in north Europe [54]. The $\mathrm{HDD}_{15}$ for the chosen climates is 1339 (Carcassonne) and 2461 (Zurich). Details of the DHW load with two-minute time step are reported in [53]. A realistic DHW profile was chosen with many variation in flow rates and large number of discharges with small flow rates. The profile was derived for a family of 
four people with the program DHWcalc, which uses statistical probabilities of different types of discharge and their flow rates and duration, and which is based on the theory described in [43].

Table 1 Climate data for Carcassonne and Zurich

\begin{tabular}{|l|l|l|l|l|l|l|}
\hline Location & Lat. & $\begin{array}{l}\text { Alt. } \\
{[\mathbf{m}]}\end{array}$ & $\begin{array}{l}\text { Design } \\
\text { Outside } \\
\text { Ambient } \\
\text { Temperature } \\
{\left[{ }^{\circ} \mathbf{C}\right]}\end{array}$ & $\begin{array}{l}\text { Average } \\
\text { Outside } \\
\text { Ambient } \\
\text { Temperature } \\
{\left[{ }^{\circ} \mathbf{C}\right]}\end{array}$ & $\begin{array}{l}\mathbf{I}_{\text {tot,45s }} \\
{\left[\mathbf{k W h} / \mathbf{m}^{2} \cdot \text { year }\right]}\end{array}$ & $\begin{array}{l}\text { Heating Degree } \\
\text { Days, } \\
\mathbf{T}_{\text {base }} \mathbf{1 5}^{\circ} \mathbf{C}, \\
\left(\mathbf{H D D}_{15}\right)\end{array}$ \\
\hline Carcassonne & $43.22^{\circ} \mathrm{N}$ & 130 & -5.0 & 13.2 & 1561 & 1339 \\
\hline Zurich & $47.37^{\circ} \mathrm{N}$ & 413 & -10.0 & 9.1 & 1306 & 2461 \\
\hline
\end{tabular}

A summary of the key figures for the four combinations is shown in Table 2. The space heating load for Carcassonne derived from annual simulations of the buildings and heating systems is less than half that for Zurich, while the annual DHW discharge energy is circa $350 \mathrm{kWh} /$ year smaller due to a higher cold water temperature. This large difference is why these climates (and buildings) were chosen.

Table 2 Key figures for the loads used in the study

\begin{tabular}{|l|c|c|c|c|}
\hline & ZH45 & ZH100 & CA45 & CA100 \\
\hline Supply temperature for DHW [ $\left.{ }^{\circ} \mathrm{C}\right]$ & 45 & 45 & 45 & 45 \\
\hline Cold water temperature for DHW $\left[{ }^{\circ} \mathrm{C}\right]$ & 10 & 10 & 10 & 10 \\
\hline $\begin{array}{l}\text { Annual DHW discharge energy } \\
{[\mathrm{kWh} / \text { year }]}\end{array}$ & 3038 & 3038 & 2691 & 2691 \\
\hline $\begin{array}{l}\text { Design Supply temperature for SH } \\
{\left[{ }^{\circ} \mathrm{C}\right]}\end{array}$ & 35 & 55 & 35 & 55 \\
\hline $\begin{array}{l}\text { Design Return temperature for SH } \\
{\left[{ }^{\circ} \mathrm{C}\right]}\end{array}$ & 30 & 45 & 30 & 45 \\
\hline $\begin{array}{l}\text { Specific SH heating demand } \\
{\left[\mathrm{kWh} /\left(\mathrm{m}^{2} \text { year) }\right]\right.}\end{array}$ & 59 & 123 & 23 & 62 \\
\hline $\begin{array}{l}\text { Annual SH demand } \\
{[\mathrm{kWh} / \text { year }]}\end{array}$ & 8269 & 17224 & 3673 & 9172 \\
\hline $\begin{array}{l}\text { Design SH load } \\
{[\mathrm{kW}]}\end{array}$ & 4.4 & 7.7 & 3.8 & 6.8 \\
\hline $\begin{array}{l}\text { Air source HP capacity at nominal } \\
\text { conditions (A2W35); } a t \\
\text { design conditions }(A-12 W 35) \\
{[\mathrm{kW}]}\end{array}$ & $8.5 ;$ & $\begin{array}{c}14.5 ; \\
5.0\end{array}$ & $\begin{array}{c}8.5 ; \\
5.0\end{array}$ & $\begin{array}{c}8.5 \\
8.2\end{array}$ \\
\hline
\end{tabular}


For this study, the space heat distribution pump was included in the total electricity use. Penalty factors for DHW production $\left(\mathrm{W}_{e l, D H W, p e n}\right)$ and $\mathrm{SH}\left(\mathrm{W}_{e l, S H, p e n}\right)$ were defined as in [55] and in addition were kept lower than $1 \%$ of total DHW energy $\left(\mathrm{Q}_{D H W}\right)$ and of total SH energy $\left(\mathrm{Q}_{S H}\right)$, respectively, for all simulations.

Total electricity use $\left(\mathrm{W}_{e l, S H P+, p e n}\right)$ and seasonal performance factor $\left(\mathrm{SPF}_{S H P+, p e n}\right)$, defined in Eq. (1) and (2), were used for the comparison of results.

$W_{e l, S H P+, p e n}=W_{e l, H P}+W_{e l, S C}+W_{e l, E H}+W_{e l, C t r}+W_{e l, d i s t}+W_{e l, D H W, p e n}+W_{e l, S H, p e n}$

$S P F_{S H P+, p e n}=\left(Q_{S H}+Q_{D H W}\right) / W_{e l, S H P+, p e n}$

where $W_{e l, H P}$ is the total electrical energy use of the heat pump, $W_{e l, S C}$ is the total electrical energy use of solar circuit, $W_{e l, E H}$ is the total electrical energy use of auxiliary electrical heater, $W_{e l, C t r}$ is the total electrical energy use of controller and $W_{\text {el,dist }}$ is the total electrical energy use of all circulation pumps.

A reference solar thermal system combined with an ASHP was defined and used as the base case for other system variations. The parameter values for the models were derived from measurement data from specific component tests carried out at test institutes or, in the case of the heat pump, from the manufacturer (see section 2.2). The heat pump was sized using a simple sizing rule for the Zurich climate and the given building, whereas the store and collector were standard sized for such solar and heat pump system packages.

Several system variations were simulated and results were compared to those of the reference system for the same climate and building according to Eq. (3) and Eq. (4).

$\Delta W_{e l, S H P+, p e n}=W_{e l, S H P+, V, p e n}-W_{e l, S H P+, p e n}$

$\Delta S P F_{S H P+, p e n}=\left(\mathrm{SPF}_{S H P+, V, p e n}-\mathrm{SPF}_{S H P+, p e n}\right) / \mathrm{SPF}_{S H P+, p e n}$

where $W_{e l, S H P+, V, p e n}$ is the total electrical energy use for the system variation and similarly for $S P F_{S H P+, V, p e n}$. A negative value of $\Delta \mathrm{W}_{e l, S H P+, p e n}$ and $\triangle \mathrm{SPF}_{S H P+, p e n}$ means a reduction in electric energy use and SPF respectively compared to the reference solution.

\subsection{Economic Analysis}

An economic model based on a comparative cost-analysis between the system variations and the reference system was developed. The framework of the model consists of Eq.(5), Eq.(6), Eq.(7) and Eq.(8) that were solved by successive iterations. 
Eq.(5) was used to define the change in annual cash flow at year $n\left(\Delta \operatorname{Cost}_{n}\right) . \Delta \operatorname{Cost}_{n}$ is calculated by summing the annuity cost $\left(\mathrm{AN}_{, n}\right)$ and the change in annual system running cost, which is calculated by multiplying the difference in total electrical energy use for the system variation compared to the reference system $\left(\Delta W_{e l, S H P+, p e n}\right)$ and the annual electricity $\operatorname{cost}\left(\mathrm{C}_{e l, n}\right)$.

Eq.(6) was used to define the uniform annuity payment, the annuity cost $\left(\mathrm{AN}_{, n}\right)$. An interest rate (i) of 3\% was assumed for $\mathrm{AN}_{, n}$. The same maintenance costs were assumed for all system variations as well as for the reference system, thus the change in maintenance costs $\left(\Delta \mathrm{M}_{n}\right)$ is set to zero. The additional investment limit $\left(\Delta \operatorname{Cost}_{10}\right)$, which is the result of Eq. (8), is an input of Eq.(6).

Eq.(7) was used to define the annual electricity cost $\left(\mathrm{C}_{e l, n}\right)$. An electricity price $\left(\mathrm{p}_{e l}\right)$ of $0.20 € / \mathrm{kWh}$ was assumed, which is the average value (with all taxes and levied included) for private householders of 27 European countries in the second semester of year 2013 [56]. The increase of $\mathrm{C}_{e l, n}$ was modelled by using a composite method based on an exponential trend $(1+\mathrm{j})^{n}$ with an annual increase of inflation (j) of $2 \%$, which is consistent to what was found in literature $[48,49]$.

Eq. (8) was used to define the additional investment limit $\left(\Delta \operatorname{Cost}_{10}\right)$ that is the maximum allowed change in cost between the system variation and the reference in order to have a payback time of 10 years. The Solver function of Excel was used to numerically identify $\Delta$ Cost $_{10}$ that gives zero for the cumulative additional cost over a period of 10 years.

$\Delta \operatorname{Cost}_{n}=\mathrm{AN}_{, n}+\mathrm{C}_{e l, n} \cdot \Delta W_{e l, S H P+, p e n}$

$\mathrm{AN}_{, n}=\Delta \operatorname{Cost}_{10} \cdot\left[\Delta \mathrm{M}_{, n}+\mathrm{i} /\left(1-(1+\mathrm{i})^{-n}\right)\right]=\Delta \operatorname{Cost}_{10} \cdot\left(\mathrm{i} \cdot(1+\mathrm{i})^{n}\right) /\left((1+\mathrm{i})^{n}-1\right)$

$\mathrm{C}_{e l, n}=\mathrm{p}_{e l} \cdot(1+\mathrm{j})^{n}$

$\Delta \operatorname{Cost}_{10}=\sum_{n=0}^{10}\left[\Delta \operatorname{Cost}_{n}\right]=0$

$\Delta \mathrm{Cost}_{10}$ was used, together with $\Delta W_{e l, S H P+, p e n}$, as key-figures for system comparison.

\subsubsection{Sensitivity analysis}

A sensitivity analysis was carried out to show the impact of the main economic parameters on the change in $\Delta \operatorname{Cost}_{10}$. Scale factors $(+50 \% ;+25 \% ;-25 \% ;-50 \%)$ were used for varying the value of interest rate (i), inflation rate $(\mathrm{j})$ and price of electricity $\left(\mathrm{p}_{e l}\right)$ from the base-case values. The scale factors were chosen so that the values of interest rate and of inflation rate were similar to those found in literature $[13,45-49,57$ - 
60]. Similarly, for electricity price the range of variation is representative of the variation trend found in European statistics [56]. The sensitivity analysis was carried out by varying one parameter at a time and by keeping the others constant (ceteris paribus).

\subsection{System Description}

A schematic of the reference system is shown in Fig.1. It is a parallel system with solar collectors that charge the hot water store via an internal heat exchanger and an ASHP that either charges the main store or serves the space heat load directly. Solar thermal consists of flat plate collectors that are tilted $45^{\circ}$ and orientated to the south. The total absorber area for four modules is $9.28 \mathrm{~m}^{2}$. The 763 liter water store has a solar coil in the lower volume and a stainless steel internal coil heat exchanger that covers the whole store height for the preparation of DHW.

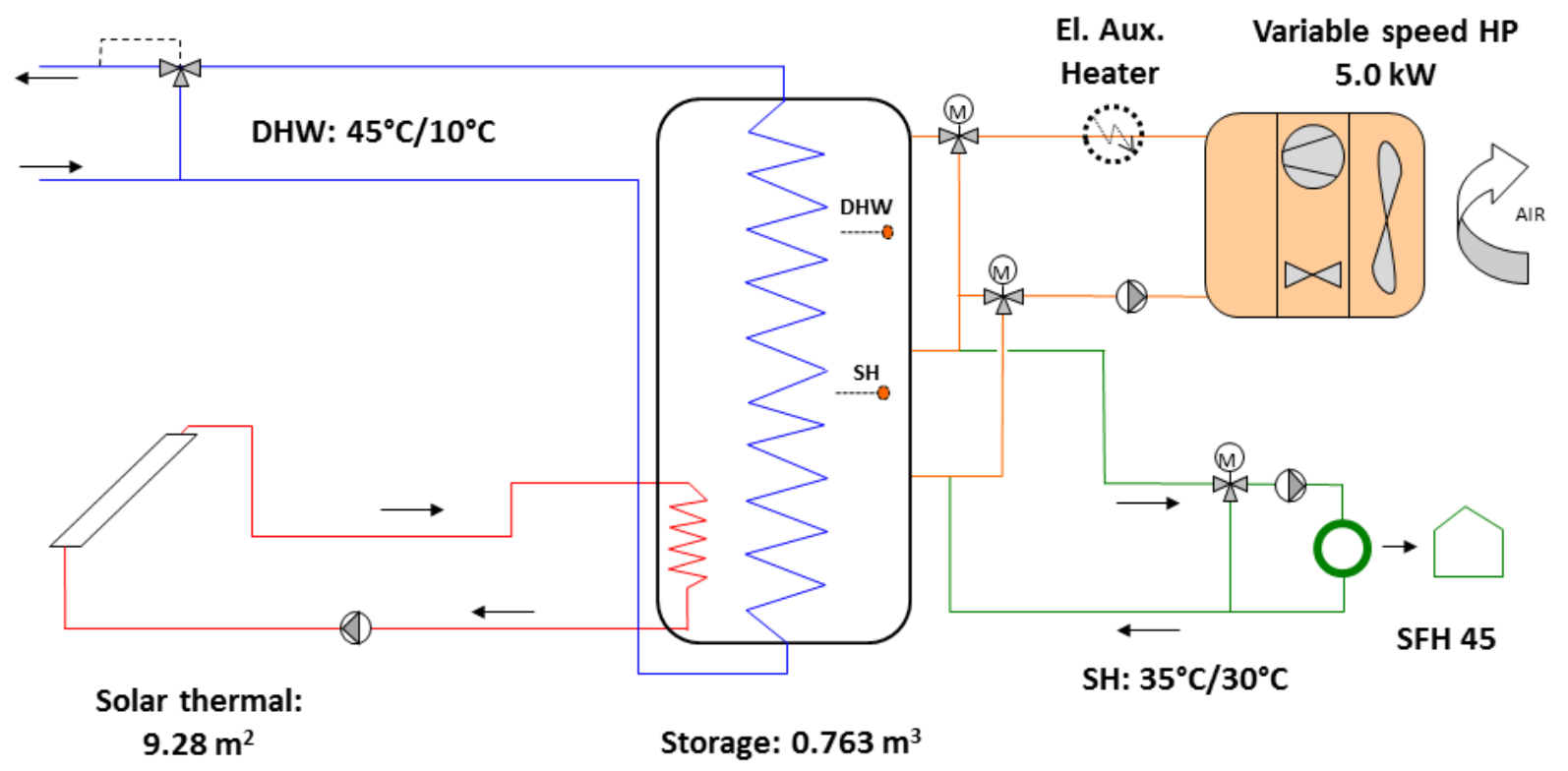

Fig. 1 Schematic of air source reference system. The position of the temperature sensors in the storage tank for space heating preparation (SH) and for hot water charge (DHW) is shown. Details of sensor heights are given in Table 4

The ASHP is a R410A split unit coupled with a scroll compressor which is variable speed controlled. In the simulation model a scale factor has been used to size the heat pump, so that it covers $100 \%$ of the load, which is common or mandatory in several European countries, and for the climate of Zurich. This results in a heating capacity that is very different for the two heat pumps at standard conditions due to the large 
difference in evaporation temperatures at design conditions. For the SFH45 house, the heat pump capacity at design conditions is $5 \mathrm{~kW}$ while at nominal conditions it is $8.5 \mathrm{~kW}$. For the SFH100 house, the heat pump capacity is 8.2 and $14.5 \mathrm{~kW}$ at design and at nominal conditions, respectively. This sizing approach is for the volumetric flow rate (compressor size) as well as heat exchanger sizes (UA-values). For the Carcassonne climate the heat pump is slightly "oversized" due to the lower design space heating load as is shown in Table 1 . The heat pump is connected to the store via three-way valves so that it charges either the upper volume for DHW preparation or the middle volume for space heating, a so called four pipe connection. The space heating loop is connected in parallel to the space heating part of the store. When the store is charged for space heating, part of the flow goes via the space heating distribution system and the rest through the store, depending on the operating conditions. The maximum flow through the heat distribution system is lower than that through the HP and is further decreased by thermostatic valves to maintain the desired room set temperature.

The supply temperature to the heat distribution system is dependent on the outside ambient temperature (heating curve) as is common in central Europe. The design supply temperatures are defined in Table 2 and design outside ambient temperature in Table 1. Different design supply temperatures are chosen as previous research has shown that the system performance of solar combisystems is very dependent on the temperature level of the heating system [29, 43,52,61], which is due to the different exergy efficiency of both the heating system and other system components [62]. Two typical design heat supply temperatures are chosen, one for radiators (higher temperature) and one for floor heating (lower temperature).

The heat pump stops and space heat is delivered from the store instead when the temperature in the return line to the heat pump goes above the current supply temperature according to the heating curve. The heat pump is started again in space heating mode when the temperature sensor in the store for heating drops below this same set point temperature minus a hysteresis of $3 \mathrm{~K}$. This temperature sensor is located in between the heat pump inlet and outlet connection of the heating volume of the store (see Fig. 1). For the ASHP with variable speed compressor, the speed is limited between $1530 \mathrm{rpm}$ and $5100 \mathrm{rpm}$ and is controlled in order to deliver the flow temperature based on the heating curve. In DHW mode the control principle is the same, with the exception that the compressor always runs at full speed during the whole charging process and the temperature sensor is located in the upper part of the store. The temperature in the upper part of the store is kept between $48^{\circ} \mathrm{C}$ and $52^{\circ} \mathrm{C}$ (on/off temperature settings for DHW mode) at the sensor due to a heat exchanger being required for DHW preparation. In the case with radiators, higher temperatures in the DHW volume of the store are possible due to higher supply temperatures required by the heating system at low outside ambient temperatures, e.g. during winter periods. In the climate of Zurich, supply temperatures above $50^{\circ} \mathrm{C}$ are required for a period of 184 hours corresponding to $3 \%$ of the 
heating season. In those conditions, the average store temperatures at the top and the SH supply temperature are $53.7^{\circ} \mathrm{C}$ and $52.6^{\circ} \mathrm{C}$, respectively.

An auxiliary heater is placed in series with the heat pump before the three-way valve between heat pump and store. The auxiliary heater switches on when the heat pump cannot supply the set point temperature for SH or DHW preparation. It switches off once the temperature of the heat pump supply line reaches the set point temperature.

\subsection{System Modelling}

The model parameters were derived for component products that are available in the market. The component model parameters are all based on experimental results, but the whole system model was not validated against measurements. Table 3 shows how system components were modelled.

Table 3 Details of how the system components were modelled. The parameters of collector, storage tank and heat pump were derived for component products while typical values were used for pumps and pipes and based from state of the art systems. Theoretical UA-value for pipe heat losses was corrected (UA $\left.\mathrm{U}_{\text {corr }}\right)$ to take into count heat losses of components and connections that are not insulated

\begin{tabular}{|c|c|c|c|c|}
\hline $\begin{array}{l}\text { Component, } \\
\text { Source for } \\
\text { Parameters }\end{array}$ & $\begin{array}{c}\text { TRNSYS } \\
\text { Type }\end{array}$ & Parameter & Unit & Value \\
\hline $\begin{array}{l}\text { Collector, } \\
{[63]}\end{array}$ & 832 & $\begin{array}{l}\text { Zero loss coefficient } \\
\text { Linear heat loss coefficient } \\
\text { Quadratic heat loss coefficient }\end{array}$ & $\begin{array}{c}- \\
\mathrm{W} / \mathrm{m}^{2} \mathrm{~K} \\
\mathrm{~W} / \mathrm{m}^{2} \mathrm{~K}\end{array}$ & $\begin{array}{l}0.79 \\
3.95 \\
0.01\end{array}$ \\
\hline $\begin{array}{l}\text { Storage Tank, } \\
{[64,65]}\end{array}$ & 340 & $\begin{array}{l}\text { Height } \\
\text { Number of Nodes } \\
\mathrm{UA}_{, T O P} \\
\mathrm{UA}_{\text {BOTTOM }} \\
\mathrm{UA}_{\text {,SIDE }} \\
\text { Volume of solar heat exchanger } \\
\left(\mathrm{UA}_{0}\right) \text { of solar heat exchanger } \\
\left(\mathrm{b}_{0}\right) \text { of solar heat exchanger } \\
\left(\mathrm{b}_{1}\right) \text { of solar heat exchanger } \\
\text { Volume of DHW heat exchanger }\end{array}$ & $\begin{array}{c}\mathrm{m} \\
- \\
\mathrm{W} / \mathrm{K} \\
\mathrm{W} / \mathrm{K} \\
\mathrm{W} / \mathrm{K} \\
\text { liters } \\
\mathrm{W} / \mathrm{K} \\
- \\
- \\
\text { liters }\end{array}$ & $\begin{array}{r}1.74 \\
100 \\
0.30 \\
0.67 \\
2.81 \\
12 \\
312 \\
0.39 \\
0.42 \\
33\end{array}$ \\
\hline
\end{tabular}




\begin{tabular}{|c|c|c|c|c|}
\hline & & $\begin{array}{l}\left(\mathrm{UA}_{0}\right) \text { of DHW heat exchanger } \\
\left(\mathrm{b}_{0}\right) \text { of DHW heat exchanger } \\
\left(\mathrm{b}_{1}\right) \text { of DHW heat exchanger }\end{array}$ & $\begin{array}{c}\mathrm{W} / \mathrm{K} \\
- \\
-\end{array}$ & $\begin{array}{l}368 \\
0.39 \\
0.86\end{array}$ \\
\hline $\begin{array}{l}\text { Heat Pump, } \\
\text { [66] }\end{array}$ & 877 & $\begin{array}{l}\text { Air volume flow rate of the evaporator } \\
\text { Swept volume flow rate of the compressor } \\
\text { Evaporating Temperature (Min, Max) } \\
\text { Condensing Temperature (Min, Max) }\end{array}$ & $\begin{array}{l}\mathrm{m}^{3} / \mathrm{s} \\
\text { liters/s } \\
{ }^{\circ} \mathrm{C} \\
{ }^{\circ} \mathrm{C}\end{array}$ & $\begin{array}{c}1.41 \\
1.89 \\
-20 ;-12 \\
22 ; 65\end{array}$ \\
\hline $\begin{array}{l}\text { Pumps, } \\
\text { [Typical values] }\end{array}$ & Equations & $\begin{array}{l}\text { Electric power of pump used in the solar loop } \\
\text { Electric power of pump used in the Heat Pump loop }\end{array}$ & $\begin{array}{l}\mathrm{W} \\
\mathrm{W}\end{array}$ & $\begin{array}{l}34 \\
12\end{array}$ \\
\hline $\begin{array}{l}\text { Pipes, } \\
\text { [Typical values] }\end{array}$ & 31 & $\begin{array}{l}\left(\mathrm{UA}_{\text {,corr }}\right) \text { Solar collector-store } \\
\left(\mathrm{UA}_{\text {, corr }}\right) \text { Heat Pump-store } \\
\left(\mathrm{UA}_{\text {, corr }}\right) \text { Store- Heat Pump } \\
\left(\mathrm{UA}_{\text {, corr }}\right) \text { Heat Pump-SH } \\
\left(\mathrm{UA}_{\text {, corr }}\right) \text { Store-DHW tempering valve }\end{array}$ & $\begin{array}{l}\mathrm{W} / \mathrm{K} \\
\mathrm{W} / \mathrm{K} \\
\mathrm{W} / \mathrm{K} \\
\mathrm{W} / \mathrm{K} \\
\mathrm{W} / \mathrm{K}\end{array}$ & $\begin{array}{l}3.81 \\
1.92 \\
1.50 \\
0.69 \\
0.86\end{array}$ \\
\hline
\end{tabular}

Type 832 QDT [67] multinode was used for modelling the collector field. Type 340 [68], which is a multiport and one dimensional multinode model, was used for modelling the thermal storage and parameters were derived from a test of a state of the art combistore according to EN 12977-3 [65]. Heat pump connections for charging the tank were modelled via two double ports as fixed inlets, one for DHW mode and one for SH mode. Space heating discharge to the heating loop was modelled via a separate double port. The simulation model assumed that the inlets to the store did not disturb the stratification due to the high flow rates that normally exist in systems with heat pumps. The effect of high flow rates on the disturbance of storage stratification for a tank of 795 liters was investigated by Haller et al. in [69] who found that significant de-stratification occurs unless active measures are made to avoid it. In this study, the destratification due to inlet mixing at high inlet velocities was not modelled explicitly, which assumes that the tanks have perfect inlet diffusers. This was justified by the fact that good inlet stratification can in practice be achieved in storage despite high inlet flow rates (Haller et al. [69]) and due to the fact that all variations use the same assumption. The spiral heat exchangers inside the store for solar and DHW preparation were modelled using Type340's internal heat exchanger model. This is a multimode model with volume of fluid in the heat exchanger and a heat transfer coefficient to the store that have to be determined empirically. The UA-value for modelling the heat transfer of heat exchangers in the store $\left(\mathrm{UA}_{H X, i n t}\right)$ is calculated according to Eq. 9 where $\dot{\boldsymbol{m}}$ is the mass flow in the heat exchanger in $\mathrm{kg} / \mathrm{s}$ and $\mathrm{T}_{\mathrm{m}}$ $\left[{ }^{\circ} \mathrm{C}\right]$ is the average of the inlet temperature to the heat exchanger and the store temperature at that level in the store [68]. 
Details of heat exchangers are shown in Table 3 together with parameters for the UA-value of the heat exchangers while details of sensor and double port connection parameters are shown in Table 4 (section 2.3.3). The total UA-value for store heat losses of $3.78 \mathrm{~W} / \mathrm{K}$ was split into top (UA,тоP), bottom

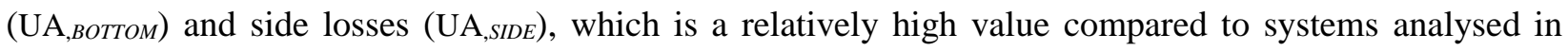
IEA-SHC Task 26 [43], resulting in heat losses of $\sim 1200 \mathrm{kWh} /$ year in Zurich for the reference system. The vertical thermal conductivity was set to $0.6 \mathrm{~W} /(\mathrm{m} \mathrm{K})$, the value for water.

Type 877 [70] was used for modelling the heat pump. Type 877 is a semi-physical model for compression heat pumps based on a calculation of the thermodynamic refrigerant cycle and the thermal properties of the used refrigerant. The thermodynamic properties of the working fluid are obtained by polynomial curve fits, which have been determined separately for the two-phase and the superheated domain of the different refrigerants. This steady state model is augmented with a simple time constant approach to consider the start- and stop behaviour and the corresponding heat pump start/stop losses. The amount of refrigerant in each of main components (compressor, heat exchangers and liquid receiver) is not modelled explicitly. Compressor heat losses were modelled as a percentage of the electrical power of the compressor and the percentage value varied according to the compressor speed and the pressure ratio. The losses caused by the icing of the air source evaporator and its defrosting were modelled in a very simple way. Depending on the evaporation temperature and the humidity of the air, a growth of ice on the evaporator is estimated. The heating capacity, which is necessary for melting the ice on the evaporator, is subtracted from the heating capacity of the condenser. The dynamics of the defrosting are not considered by the model, so melting occurs at every time step, as ice is accumulated. An additional defrost efficiency of 0.5 was used to increase the defrosting losses in all simulated cases. This value was determined from laboratory measurements with 69 different operating points ${ }^{1}$ of an ASHP, in order to fit the model for operating conditions with defrosting. A scale factor approach was used to size the heat pump so that it could supply $100 \%$ of the design heating load for the climate of Zurich and for each of the two buildings. The scale factor was used for the UA-values of heat exchangers, the swept volume flow rate of heat pump compressor, mass flow of condenser (water side) and evaporator (air side) while the overall isentropic and volumetric efficiencies of the compressor were kept the same.

\footnotetext{
${ }^{1}$ Measurements were carried out by an industry partner in accordance with EN 14511; operating conditions ranging from air inlet temperature at the evaporator from -15 to $30{ }^{\circ} \mathrm{C}$ and water outlet temperature at the condenser from 35 to $55^{\circ} \mathrm{C} ; 32$ out of the 69 measured operating points were with defrosting;
} 
Pipes connecting the collector to the store and between store and heat pump were modelled explicitly using Type 31. The dimension of the pipes in the collector circuit was defined according to prEN 12977 2:2007 [71] depending on the flow rate, as was the insulation standard. The insulation standard of the other pipes was defined using the same standard, but the pipe diameter was chosen according to thumb rules used by plumbers. Pipe runs were estimated for a standard installation resulting in $30 \mathrm{~m}$ piping in the collector loop (internal diameter $16 \mathrm{~mm}$ ) and a total of $22 \mathrm{~m}$ for all the other pipes (internal diameter 25 $\mathrm{mm}$ ). The heat loss UA-value for the pipes was calculated theoretically based on the insulation level but adjusted for heat losses from connections and pipes. $0.085 \mathrm{~W} / \mathrm{K}$ (equivalent to a bare copper pipe of $0.1 \mathrm{~m}$ with diameter $0.035 \mathrm{~m}$ ) was added for each connection and $0.17 \mathrm{~W} / \mathrm{K}$ for each component such as a valve (equivalent to a bare copper pipe of $0.2 \mathrm{~m}$ with diameter $0.035 \mathrm{~m}$ ). In total 18 connections and 10 components were included.

The electricity use of the circulation pumps was not derived from the component models but was calculated separately in a set of equations using a nominal power for set conditions of pressure drop and mass flow rate. In the solar loop a pressure drop of 0.4 bar and a mass flow rate of $0.10 \mathrm{~kg} / \mathrm{s}$ were used. Similarly, 0.2 bar and $0.24 \mathrm{~kg} / \mathrm{s}$ were considered in the heat pump loop. Corrections were applied depending on the actual flow rate and the (linear) dependency of the efficiency on the flow rate. Nominal efficiencies of $12 \%$ for the solar loop pump and $40 \%$ for the pumps used for charging the store from the heat pump were used. A fixed power of $15 \mathrm{~W}$ was used for the high efficiency SH distribution pump.

\subsubsection{Vapour injection}

Fig. 2 shows a schematic of the heat pump with (right) and without (left) vapour injection. In the solution with vapour injection the refrigerant enters the compressor on the low pressure side (evaporation pressure) from the suction line. While the refrigerant is compressed to the condensation pressure level, additional refrigerant is injected from the flash tank at an intermediate pressure, thus increasing the refrigerant mass flow on the high pressure compared to the low pressure side. After compression the refrigerant enters the condenser, where the water circulating in the space heating loop is heated or the rejected heated is used for charging the storage tank. The first expansion valve expands from high pressure to the intermediate pressure level where, in the flash-tank the separation between the liquid phase and the vapour phase refrigerant occurs. The saturated vapour passes the mid-stage injection port of the compressor and the liquid state of the refrigerant in the flash tank is expanded to the low pressure stage by the second expansion valve. The refrigerant enters the evaporator, where it is evaporated and superheated by the heat source. After passing the evaporator the refrigerant cycle is closed with the suction line to the compressor. 
Type 877 was extended and a vapour injection cycle with a liquid receiver (flash-tank) was included. In the model the injection port position can be defined by means of the ratio of the high pressure section of the compressor's swept volume to the total compressor's swept volume. A value of $65 \%$ was assumed in the study, which results in approximately the same pressure ratio for the first and second compression stage in the most operating conditions.

Refrigerant in saturated vapour phase (from the flash tank) was considered entering the compressor at the middle stage injection port. Isentropic and volumetric efficiencies were modelled by using the same approach and the same efficiency data as for the reference heat pump system and for both stages of compression. However, both volumetric and isentropic efficiency will very likely be influenced by the vapour injection, but unfortunately no data was available concerning a direct comparison of the performance of a compressor with and without vapour injection. The extended HP model with vapour injection was validated with laboratory measurements ${ }^{2}$ with a brine-water HP with a vapour injection cycle. The results showed a good agreement with measurements, more details about this work can be found in [72].
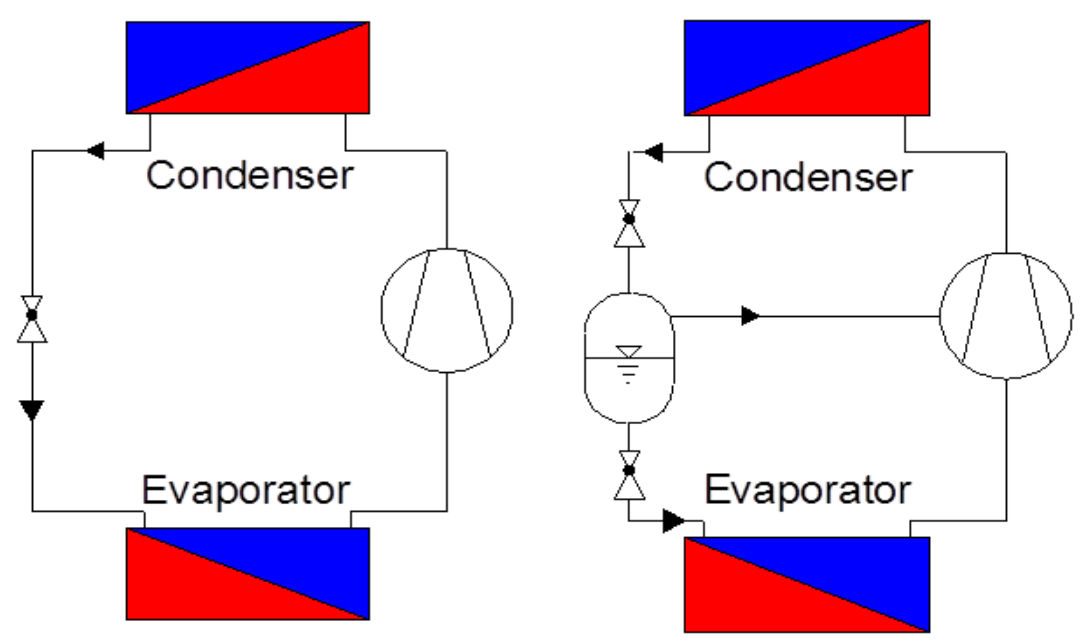

Fig. 2 Schematic of the heat pump with (right) and without (left) vapour injection

As is shown in Fig. 3, the heating capacity and the coefficient of performance (COP) of the heat pump solution with vapour injection is $22 \%$ larger and $17 \%$ higher, respectively, than for a standard refrigerant cycle, when the same swept volume of the compressor is assumed. The higher heating capacity is due to

\footnotetext{
273 different steady state operating conditions ranging from brine inlet temperature at the evaporator from -10 to $12{ }^{\circ} \mathrm{C}$ and water outlet temperature at the condenser from 22 to $60^{\circ} \mathrm{C}$;
} 
the higher refrigerant mass flow rate on the high pressure side due to the vapour injection. As the increase in heating capacity is larger compared to the increase in compressor's electrical power this results in $17 \%$ increase of heat pump COP. In order to achieve the same sizing at design conditions (A-12W35) as for the reference heat pump, the swept volume of the compressor with vapour injection was sized $20 \%$ smaller.
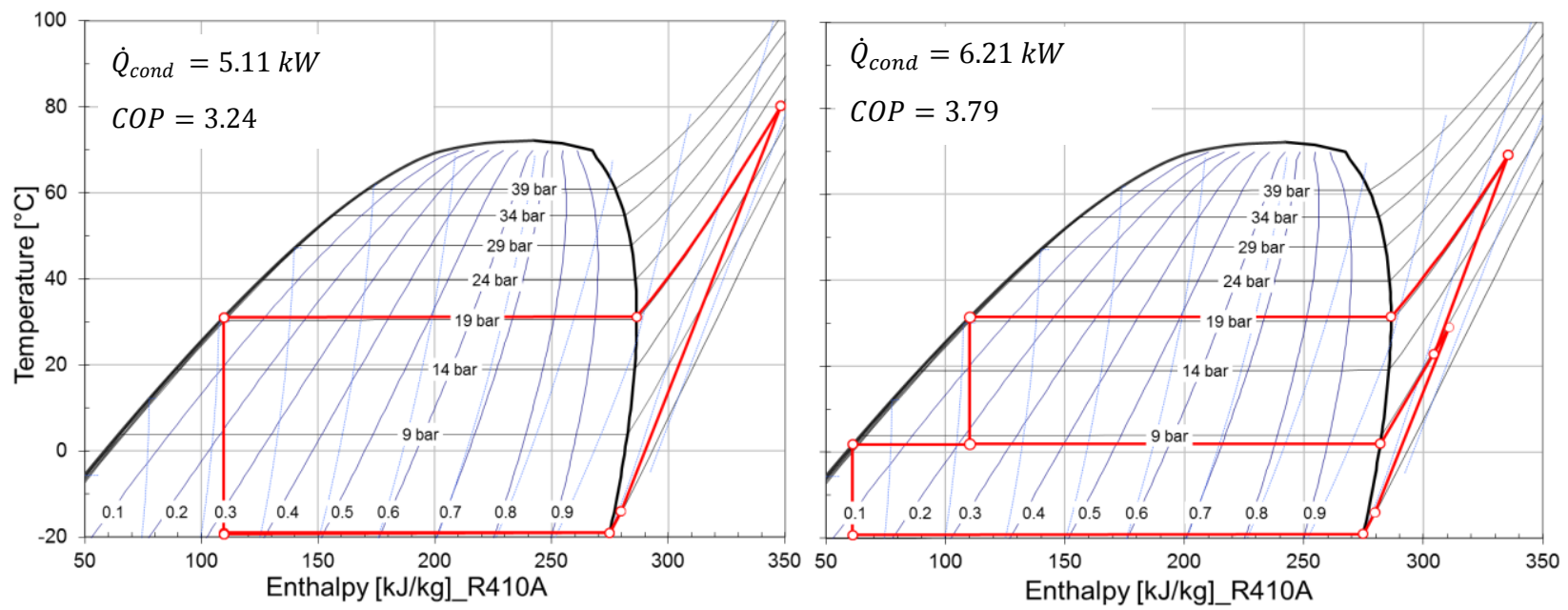

Fig. 3 Heat pump cycle in the Temperature-Enthalpy diagram of the system with (right) and without (left) vapor injection

\subsubsection{Variable speed compressor}

The variable speed (VS) compressor of the reference ASHP was replaced by a constant speed (CS) compressor. The overall isentropic efficiency and the volumetric efficiency of the CS compressor were derived from those of the VS compressor at a frequency of $50 \mathrm{~Hz}$, which is close to the optimum frequency of this compressor concerning the isentropic efficiency. The swept volume of the CS was increased compared to the VS compressor in order to achieve the same heating capacity at design conditions. An additional efficiency for the inverter was included, meaning that the value of the isentropic efficiency of the CS compressor was increased by $3.5 \%$ compared to the value of isentropic efficiency of the VS compressor at $50 \mathrm{~Hz}$.

\subsubsection{Four pipe connection between heat pump and storage tank}

The heat pump is connected to the store via three pipes, which can be used like "four pipe" or "three pipe" connection. In the case of the four pipe connection (Fig. 4 right) the heat pump is connected to the store on 
the top and on the middle of the tank, respectively for charging the DHW part of the store. In the case of the three pipe connection (Fig.4 left) the return flow of the heat pump comes from the bottom connection of the tank instead. Thus, the hotter water in the DHW zone is pushed down into the SH zone leading to higher temperatures than necessary there, while with four pipes connection, only the upper (DHW zone) is heated. The four pipe connection was part of the reference system and, compared to the three pipe, was modelled with an extra three way valve between heat pump and storage tank as well as an extra pipe on the return line between storage tank and heat pump. The position of sensors in the store, the connection from the store to the DHW circuit and to the SH circuit, the connection from the solar field to the store were kept the same in both layout configurations. Details of sensor and double port connection parameters are given in Table 4 for solutions with three pipe connection and four pipe connection.

Table 4 Sensor and double port connection parameters for both three pipe (3p, given as left hand figure) and four pipe (4p, given as right hand figure). All heights are given as relative to the height of the store, with zero being at the bottom

\begin{tabular}{|l|c|c|c|c|c|}
\hline Parameter & $\begin{array}{c}\text { Heat pump } \\
\text { DHW charge }\end{array}$ & $\begin{array}{c}\text { Heat pump } \\
\text { SH charge }\end{array}$ & Solar charge & SH discharge & $\begin{array}{c}\text { DHW } \\
\text { discharge }\end{array}$ \\
\hline inlet height & $1.0 / 1.0$ & $0.49 / 0.49$ & $0.45 / 0.45$ & $0.26 / 0.26$ & $0.03 / 0.03$ \\
[-] & $(3 \mathrm{p} / 4 \mathrm{p})$ & $(3 \mathrm{p} / 4 \mathrm{p})$ & $(3 \mathrm{p} / 4 \mathrm{p})$ & $(3 \mathrm{p} / 4 \mathrm{p})$ & $(3 \mathrm{p} / 4 \mathrm{p})$ \\
\hline outlet height & $0.49 / 0.26$ & $0.26 / 0.26$ & $0.00 / 0.00$ & $0.49 / 0.49$ & $0.95 / 0.95$ \\
{$[-]$} & $(3 \mathrm{p} / 4 \mathrm{p})$ & $(3 \mathrm{p} / 4 \mathrm{p})$ & $(3 \mathrm{p} / 4 \mathrm{p})$ & $(3 \mathrm{p} / 4 \mathrm{p})$ & $(3 \mathrm{p} / 4 \mathrm{p})$ \\
\hline $\begin{array}{l}\text { Sensor height } \\
{[-]}\end{array}$ & $\begin{array}{c}0.65 / 0.65 \\
(3 \mathrm{p} / 4 \mathrm{p})\end{array}$ & $\begin{array}{c}0.44 / 0.44 \\
(3 \mathrm{p} / 4 \mathrm{p})\end{array}$ & $\begin{array}{c}0.18 / 0.18 \\
(3 \mathrm{p} / 4 \mathrm{p})\end{array}$ & - & - \\
\hline
\end{tabular}
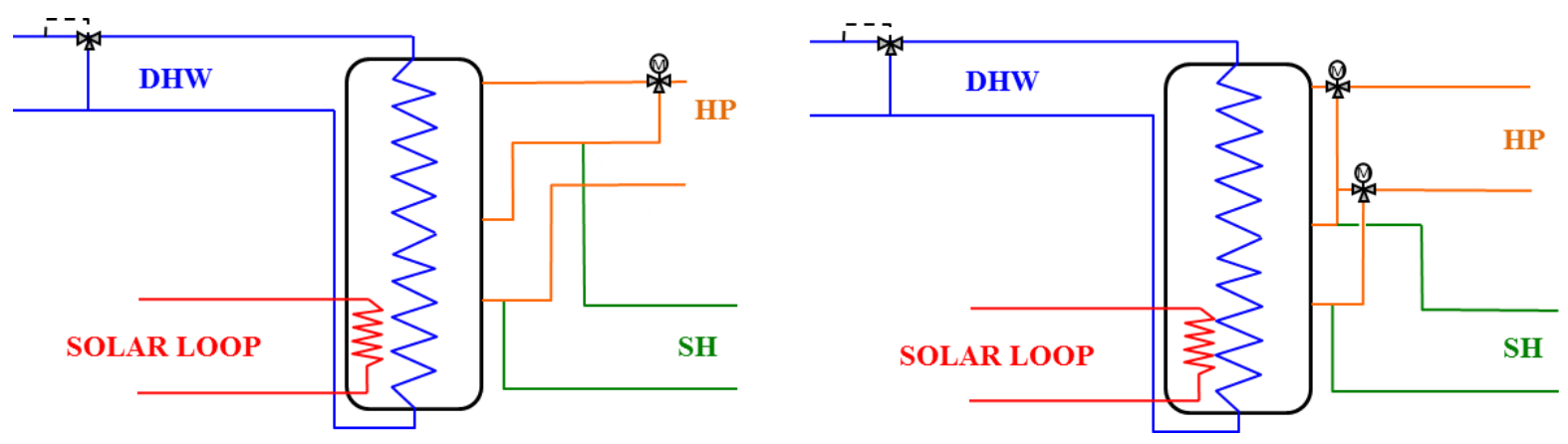

Fig. 4 Schematic of three pipe connection (left) and four pipe connection (right) between heat pump and storage tank 


\subsubsection{Four way-valve in the space heating circuit}

Fig. 5 shows the schematic of system with four-way valve for SH. The four-way valve takes heat from two sources: from the standard connection in the reference system (directly from the heat pump or from the middle of the store); from an outlet in the store lower down than the standard outlet and also below the temperature sensor controlling the charging of the space heat part of the store.

Type 221 [73] was used for modelling the four-way valve. An extra pipe to the store was modelled via a double port. Details of connection heights to the store and sensor placement are given in Table 4. The outlet of the lower double port, connected to the middle port of the four-way valve was located at a relative height of 0.40 while the outlet/inlet for the existing connection and the relative height of the $\mathrm{SH}$ sensor were kept at 0.49 and at 0.44 , respectively. The inlet from the heating system was 0.26 for both double ports.

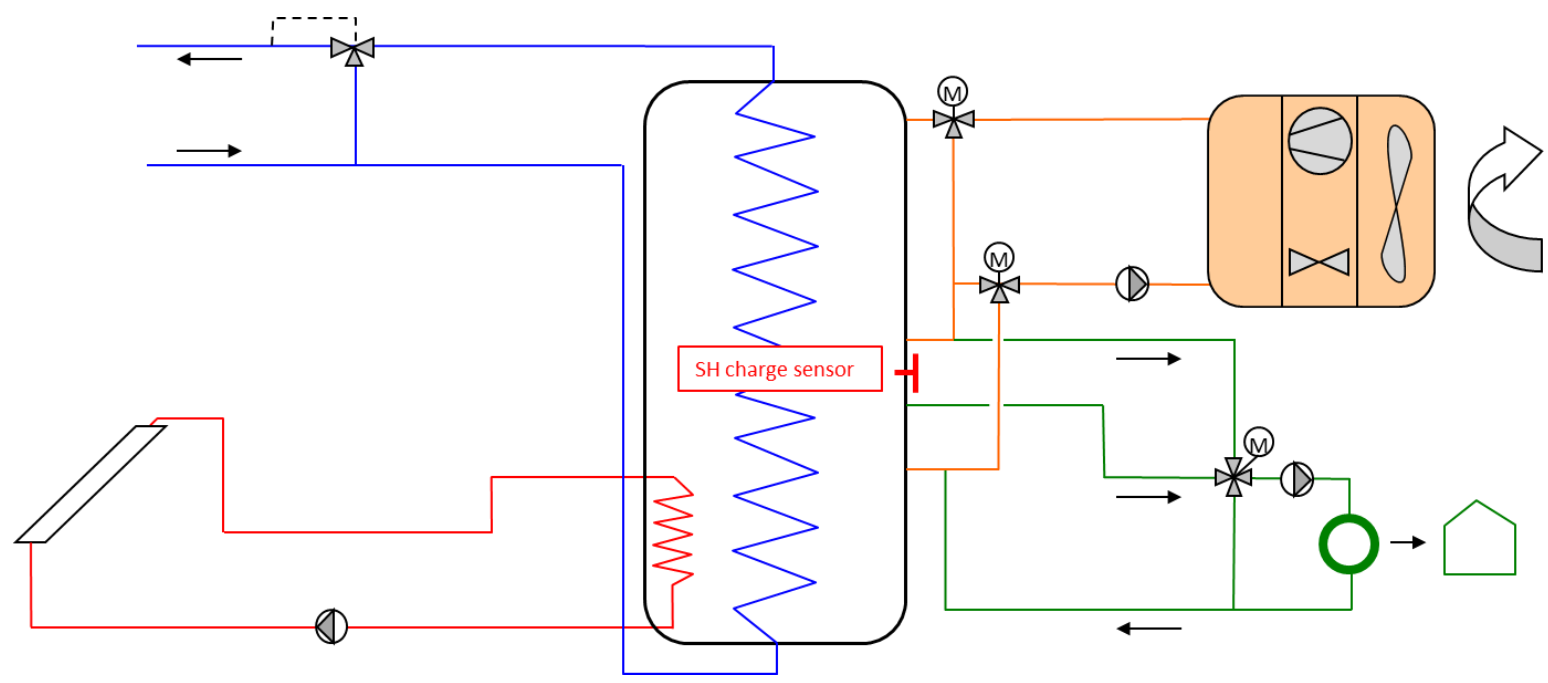

Fig. 5 Schematic of system with four-way valve for SH

\subsubsection{Vacuum insulation techniques on the storage tank}

A new design of the storage insulation was simulated that uses VIP's to lower the heat losses. Fig. 6 shows the new rectangular insulation for the reference system, which also includes most system components under the insulation. All pipes were assumed to be connected to the bottom of the store. For convenience, the heat emissions of the components under the insulation were still calculated as losses in the same way as for the reference system even if there could be some decreases in losses in reality due to higher surrounding temperatures for the pipes. The VIP insulation of $20 \mathrm{~mm}$ thickness is embedded in a protecting layer of plastic on each side. The overall tank dimensions including VIP insulation are shown in 
Fig. 6. The thermal conductivity of VIP's was assumed to be $0.0035 \mathrm{~W} / \mathrm{mK}$ [74]. The bottom of the storage is only insulated by a polyurethane (PUR) foam of $30 \mathrm{~mm}$ thickness. The thermal conductivity of PUR was assumed to be $0.03 \mathrm{~W} / \mathrm{mK}$. At the connection edges of the insulation plates an additional insulation of PUR foam was added to avoid thermal bridges (radius of $200 \mathrm{~mm}$ ). The following UA-values were used for the simulation, with the reference values shown in brackets; for the bottom insulation 1.06 $(0.67) \mathrm{W} / \mathrm{K}$, for the top insulation $0.18(0.3) \mathrm{W} / \mathrm{K}$ and for the side insulation $1.32(2.81) \mathrm{W} / \mathrm{K}$.
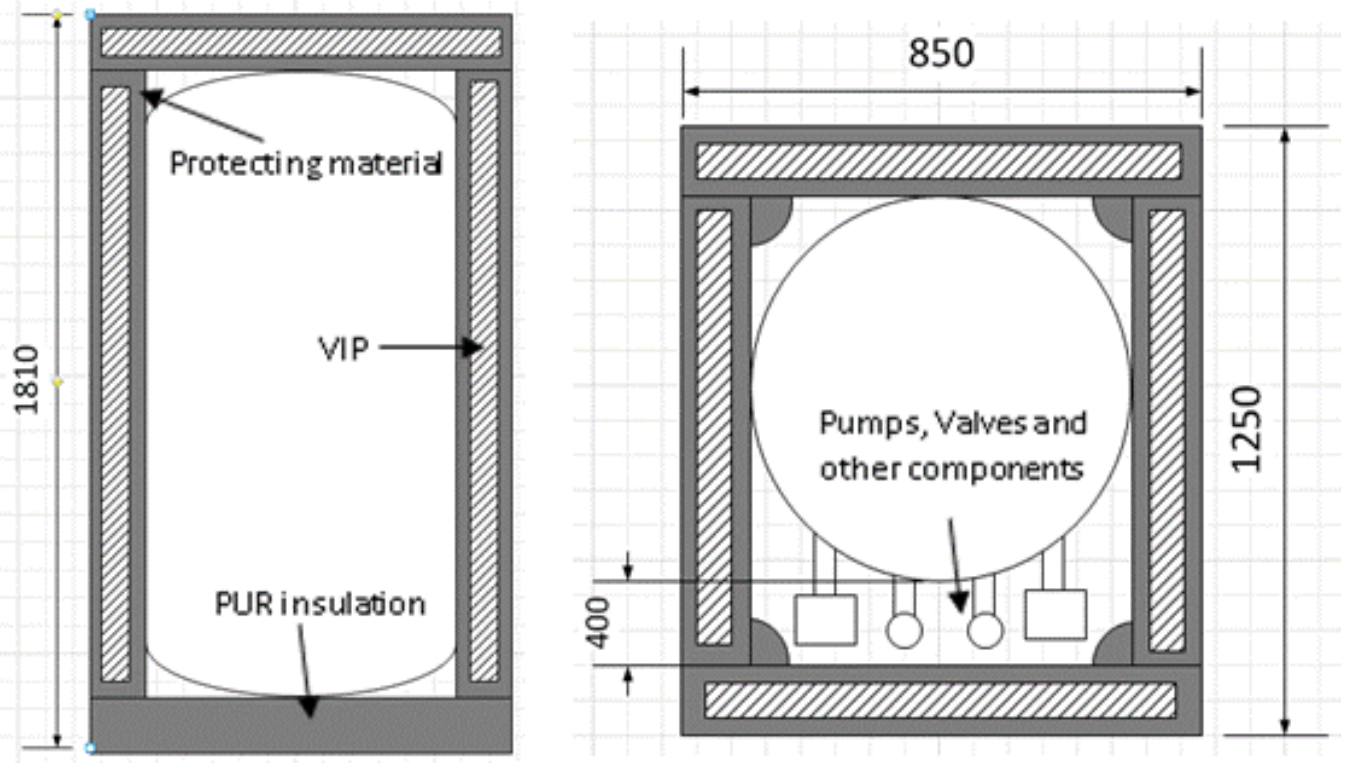

Fig. 6 Drawing of the quadratic VIP insulation. Overall dimensions are given in $\mathrm{mm}$

\subsubsection{Heat pump condenser integrated in the storage tank}

Fig. 7 (left) shows the investigated solution with the condenser of heat pump integrated into the storage tank and the refrigerant medium that flows in an immersed heat exchanger. Such a solution could not be simulated as is shown due to the limitation of the store model (Type 340) that did not allow the modelling of an internal heat exchanger with the use of refrigerant. Instead, the schematic of Fig. 7 (right) was simulated. A water loop was modelled for transferring the condenser heat of the heat pump to an immersed heat exchanger in the tank. The immersed heat exchanger was modelled similarly to the solar heat exchanger, but with a $60 \%$ higher UA-value based on the fact that the design heat transfer rate for this heat exchanger is $60 \%$ higher than for the collector heat exchanger. Heat pump connections to the tank were modelled so that the inlet of the immersed heat exchanger had the same height of the outlet of the space heating discharge loop. The fictive heat pump condenser was modelled by assuming a fixed UAvalue of $6000 \mathrm{~W} / \mathrm{K}$, a high value in order to have a small temperature difference between refrigerant and 
the water in the fictive loop between condenser and the internal heat exchanger. No heat losses were considered in the fictive water loop as well as no electrical consumption for the circulation pump between heat pump condenser and internal heat exchanger. This modeling approach results in a $3.5 \mathrm{~K}$ temperature difference between inlet and outlet water temperature of the internal heat exchanger, the inlet temperature being $0.8 \mathrm{~K}$ higher than the condensation temperature of the refrigerant. There is a temperature difference of $2.0 \mathrm{~K}$ between the temperature of the water in the store and that inside the heat exchanger at the same height in the store. In a real system, with refrigerant inside the internal heat exchange, there would be a high temperature at the top of the heat exchanger where there is superheated refrigerant, while the majority of the heat exchanger would have condensation on the inside at the condensation temperature. Thus the modeling approach leads to a lower degree of stratification in the store over the height of the heat exchanger than there would be in a real system, but the temperature difference between condensation temperature and store temperature is realistic. A $6 \mathrm{~kW}$ backup electric heater in the tank replaced the electrical heater of the reference system, which was placed in the heat pump flow line before the threeway valve. 


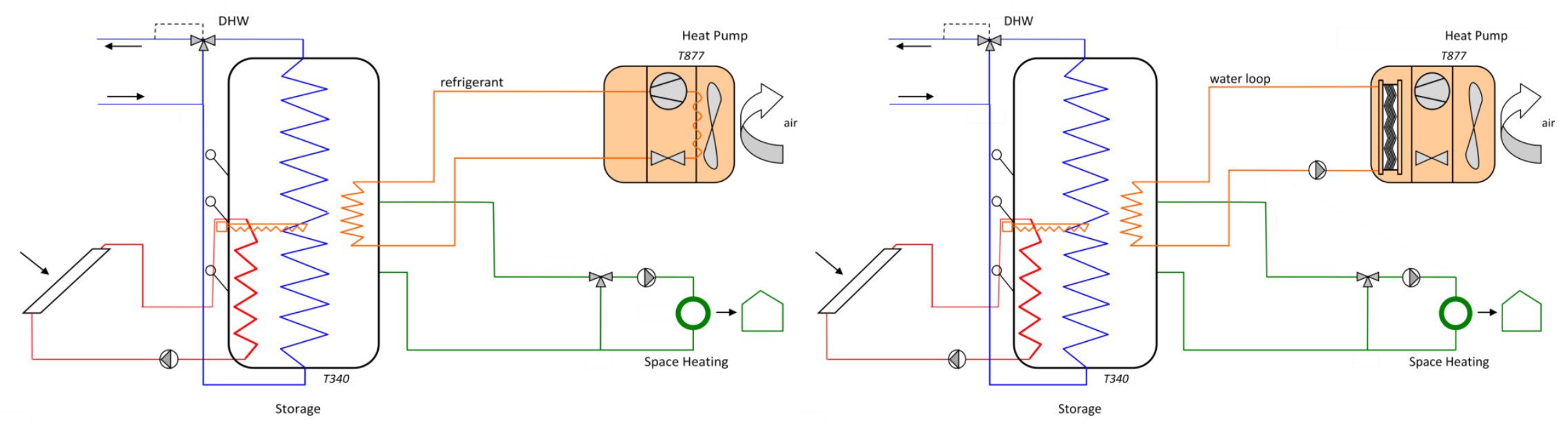

Fig. 7 System with the heat pump condenser integrated in the storage tank: schematic of the investigated system (left) and schematic of the modelled system (right). 


\section{Results and Discussion}

\subsection{Reference System}

Table 5 shows results for the reference system for the range of two climates and two buildings. $\mathrm{W}_{e l, S H P+, p e n}$ varies from 1655 to $8340 \mathrm{kWh} /$ year while $\mathrm{SPF}_{S H P+, p e n}$ varies from 3.85 to 2.43 in reverse order. This gives a wide range of conditions in electricity use and a smaller range of conditions in $\mathrm{SPF}_{S H P+, p e n}$.

Table 5 SPF and total electricity use for the two reference systems for the two climates and buildings

\begin{tabular}{|c|c|c|c|c|}
\hline & AZ45 & AZ100 & AC45 & AC100 \\
\hline $\begin{array}{c}\mathrm{SPF}_{\text {SHP+,pen }} \\
{[-]}\end{array}$ & 3.16 & 2.43 & 3.85 & 2.93 \\
\hline $\begin{array}{c}\mathrm{W}_{\text {el,SHP+,pen }} \\
{[\mathrm{kWh} / \text { year }]}\end{array}$ & 3581 & 8340 & 1655 & 4055 \\
\hline
\end{tabular}

The SPF values for Carcassonne are better than those shown for similar system in IEA SHC Task 44 / HPP Annex 38 [52] for Strasbourg while those of Zurich are slightly lower. This is true for both the SFH45 and SFH100 buildings that are the same in both studies. This is consistent with the difference in climate conditions of Strasbourg that has an average ambient temperature that is between that of Carcassonne and Zurich.

Fig. 8 shows the overall system energy balances for the reference system. Solar collector energy and store energy losses are in the amount of 3869 and $1178 \mathrm{kWh}$ a year respectively. Auxiliary losses are in the amount of $1610 \mathrm{kWh}$ a year and include the start/stop losses of heat pump cycle, the compressor heat losses to ambient and losses due to defrosting of the outdoor evaporator heat exchanger. The compressor heat losses to the ambient cover $\sim 70 \%$ of auxiliary losses. The reason for the larger share is that the ASHP is a split-system, which is normally employed in air-conditioning, and thus the compressor is not optimized for heating purposes. Losses due to the defrosting are in the amount of $318 \mathrm{kWh}$ a year and are bigger than the start/stop losses.

More details of the energy balances of the store and the heat pump for the reference system can be found in [75]. 
口El. Aux Heater

口Heat Pump Evaporator

口Solar Collector (direct)

口El. Compressor

口TES Losses

口Pipe \& HX losses

$\square$ Auxiliary Losses

aDHW

口Space Heat

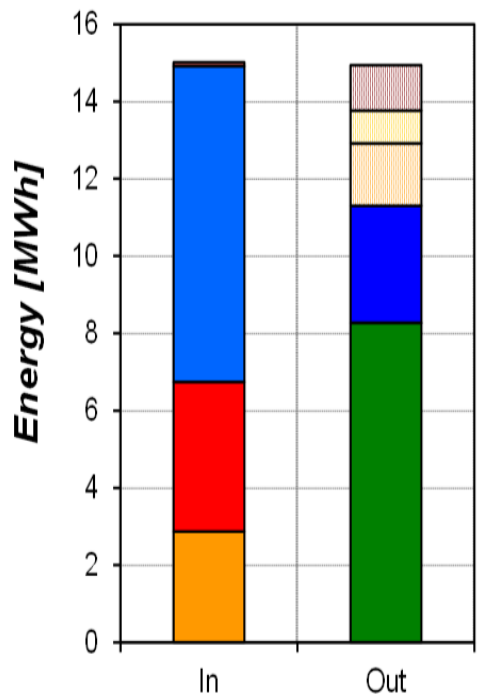

Fig. 8 Overall system energy balances for the reference system

Tab. 6 shows the electricity use in the reference system. The use of the electrical auxiliary heater is relatively small while the heat pump compressor uses $80 \%$ and circulation pumps only use $4 \%$. The fan uses $8 \%$ while the parasitic energy consumption of controllers and electric devices has a share of $5 \%$.

Tab. 6 Electricity use of reference system

\begin{tabular}{|c|c|c|}
\hline & $\mathbf{k W h} / \mathbf{y e a r}$ & \% of $\mathbf{W}_{\boldsymbol{e l}, \text { SHP+,pen }}$ \\
\hline HP compressor & 2876 & 80 \\
\hline HP ventilator & 287 & 8 \\
\hline Parasitic & 175 & 5 \\
\hline Pumps & 129 & 4 \\
\hline El. Aux. Heater & 101 & 3 \\
\hline
\end{tabular}

\subsection{Vapour injection}

Fig. 9 shows the change in $\Delta \mathrm{W}_{e l, S H P+, p e n}$ (bottom) and $\Delta$ Cost $_{10}$ (top) for the whole matrix of variation of buildings/climate. The y-axis shows the changes in $\Delta \operatorname{Cost}_{10}$ in $(€)$ on top left and changes in $\Delta \mathrm{W}_{e l, S H P+, p e n}$ 
in ( $\mathrm{kWh} /$ year) on bottom right. For each combination building/climate, the results of the sensitivity analysis (Fig. 10) are also given and are shown with the use of error bars. The value of the error bars corresponds to the change in $\Delta \operatorname{Cost}_{10}$ with electricity price $(0.1 € / \mathrm{kWh}$ and $0.3 € / \mathrm{kWh})$ with fixed, default values for the other economic parameters.

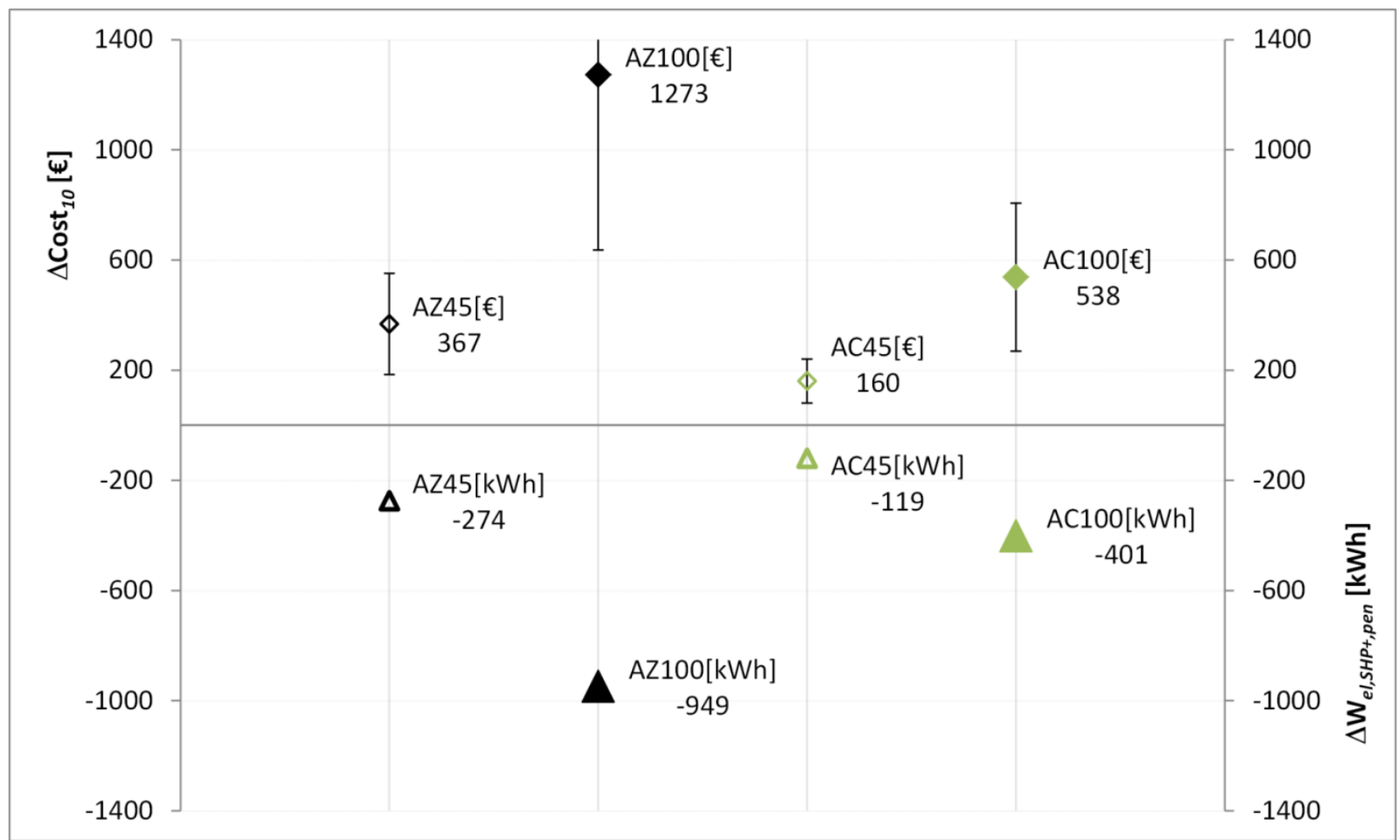

Fig. 9 Changes in system electricity $\Delta \mathrm{W}_{e l, S H P+, p e n}$ (bottom) and additional investment limit $\Delta \operatorname{Cost}_{10}$ (top) for the study of vapor injection. Error bars show range for electricity price of $0.1-0.3 € / \mathrm{kWh}$

$\Delta \mathrm{W}_{e l, S H P+, p e n}$ varies from $119 \mathrm{kWh} /$ year for the SFH45 house in Carcassonne to $949 \mathrm{kWh} / \mathrm{year}$ for the SFH100 in Zurich. The changes in $\Delta \mathrm{W}_{e l, S H P+, p e n}$ are smaller for Carcassonne than for Zurich due to higher ambient temperatures and therefore lower pressure ratios, which cause a lower benefit of the economizer cycle compared to Zurich. Absolute values are also lower due to the smaller demand in Carcassonne. $\triangle S P F_{S H P+, p e n}$ in percentage varies from $7 \%$ for the SFH house in Carcassonne to $11 \%$ for the SFH100 in Zurich. Results for heat pump systems with no solar ([6]) showed $9.4 \%$ improvement in COP for the case with injection cycle compared to a case with non-injection cycle and this is within the range of variation shown in this study. 
Relative differences in $\Delta \mathrm{W}_{e l, S H P+, p e n}$ are larger for the SFH100 house (12\%) than for the SFH45 (8\%) but the difference between results for Zurich and Carcassonne were small. Percentage changes are similar in several cases, but absolute values vary considerably for different buildings and climates and this affects the cost effectiveness of the solutions as it is dependent on the absolute energy savings and not the relative savings.

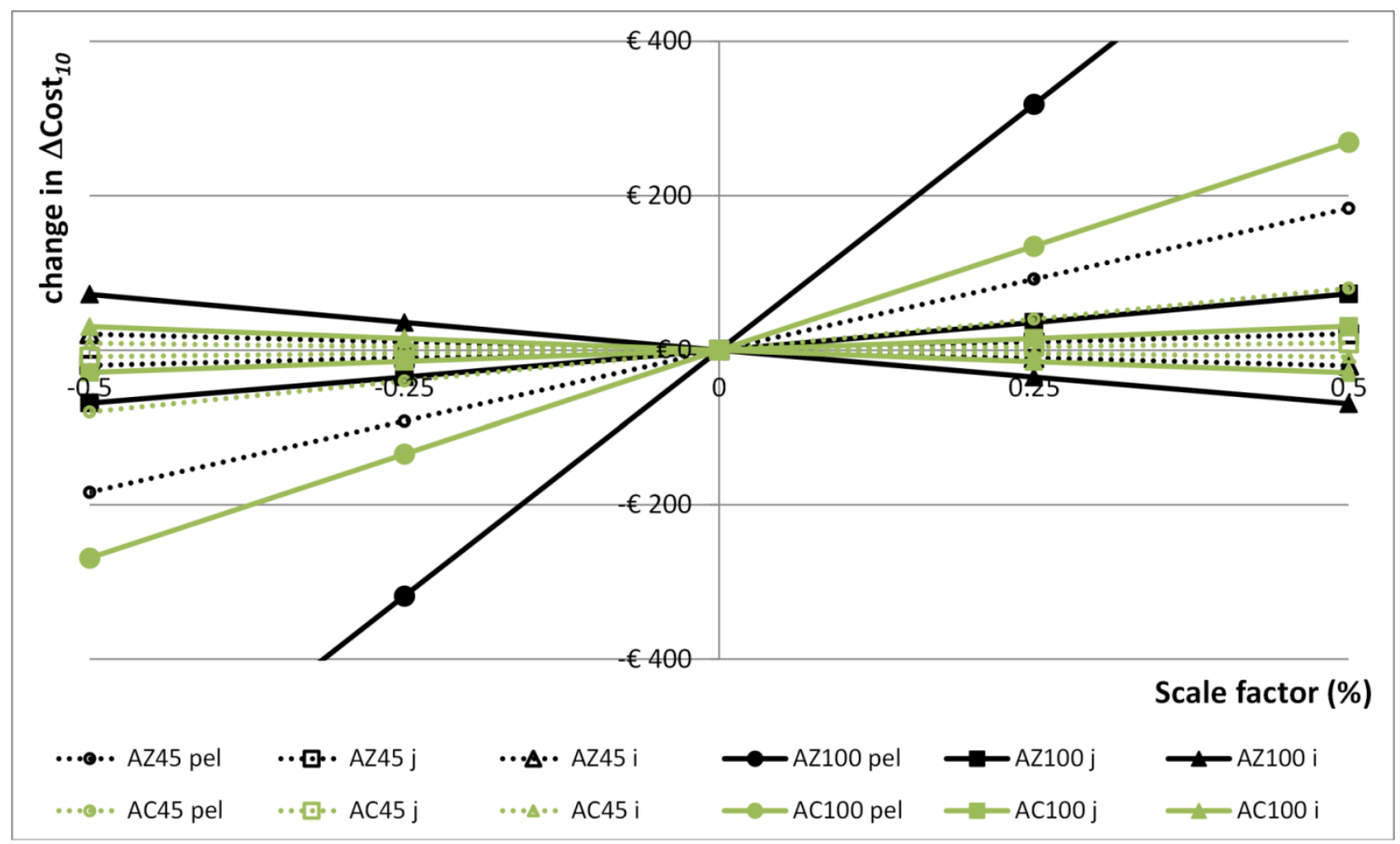

Fig. 10 Changes in $\Delta \mathrm{Cost}_{10}$ for variation of assumed economic parameters: electricity price (pel), inflation rate (j) and interest rate (i). Scale factors in percentage were used for varying the values from the base-case. Changes in $\Delta$ Cost $_{10}$ in $€$ are shown for the scale factors

$\Delta \mathrm{Cost}_{10}$ varies similarly to $\Delta \mathrm{W}_{e l, S H P+, p e n}$ and from $160 €$ to $1273 €$. The changes in $\Delta \operatorname{Cost}_{10}$ are bigger for the SFH100 than for the SFH45 and for Zurich than for Carcassonne. Fig. 10 shows results of the sensitivity analysis on electricity price, inflation rate and annuity interest rate. The y-axis shows the absolute difference in $\Delta \operatorname{Cost}_{10}$ in $€$. The $\mathrm{x}$-axis shows the range of variation in electricity price $\left(\mathrm{p}_{e l}\right)$, inflation rate (j) and interest rate (i). The total range of $\Delta \operatorname{Cost}_{10}$ for both houses varies from $184 €(0.1 € / \mathrm{kWh}$ electricity price) to $1909 €(0.3 € / \mathrm{kWh}$ electricity price) for Zurich and similarly from $80 €$ to $807 €$ for Carcassonne. The trend of variation of $\Delta$ Cost $_{10}$ is similar for both the SFH45 and the SFH100 and for both Zurich and 
Carcassonne and thus the consistency and robustness of the economic model is shown. $\Delta$ Cost $_{10}$ is more sensitive to the variation of electricity price than to the variation of inflation rate and annuity interest rate. Similar trend was noticed for all system variations, thus only figures of $\Delta \operatorname{Cost}_{10}$ for the different boundaries are shown for the other studies.

A vapour injection heat pump unit needs a supplementary liquid receiver (flash tank) and an additional expansion valve as well as an extra pipe for connecting the flash tank to the compressor. Moreover, the compressor requires an injection port for the vapour refrigerant at intermediate pressure. This will lead to a significant increase in costs, but as the additional investment limit is shown to be high, there is good potential that this can be cost-effective. Vapour injection is more attractive for the house standard SFH100 than for the SFH45 and in Zurich compared Carcassonne.

\subsection{Variable speed compressor}

Fig. 11 shows the change in $\Delta \mathrm{W}_{e l, S H P+, p e n}$ (bottom) and $\Delta \mathrm{Cost}_{10}$ (top) for the study of VS compressor. Since the reference system is with VS compressor, results must be interpreted as changes for the system with CS compressor compared to the reference. VS compressor is shown to have significantly lower electricity use for the SFH100 house in Zurich, while for Carcassonne the difference is small ( $<50 \mathrm{kWh} / \mathrm{year})$. For the SFH45 house, CS compressor is shown to have lower electricity use, but differences are small $(<40$ $\mathrm{kWh} /$ year).

These results are explained by the fact that VS compressor reduces start/stop and defrost losses by 24 $38 \%$, and is dependent on heat pump running time. Defrost losses decrease due to higher evaporator temperatures. For the SFH100 house, the storage capacity of the heating system is lower because radiator heating system has been used while for the SFH floor heating is used and this gives longer running time. The reduction of start/stop losses and defrost losses is thus less pronounced in the case with the SFH45 house due to the higher storage capacity of floor heating system.

$\Delta$ Cost $_{10}$ must be interpreted as the additional cost of the VS compressor in comparison to the CS compressor. For the SFH100 house, negative values of $\Delta$ Cost $_{10}$ are interpreted as cost benefits for the VS compressor compared to the CS compressor. Higher cost benefits are noticed in Zurich and this can be explained by the larger use of electricity. For the SFH45 house in Carcassonne, CS compressor has higher cost benefits than VS compressor. However, changes are very small and slightly over $70 €$ in the case of higher electricity price $(0.3 € / \mathrm{kWh}$ electricity price). For the SFH45 house in Zurich, there are almost no changes in $\Delta \operatorname{Cost}_{10}$. 
The VS compressor has smaller swept volume than the CS compressor, but requires an additional inverter for adjusting the speed and thus it is difficult to say which solution leads to higher/lower costs. Variable speed is attractive for the house standard SFH100 and in colder climate more than in warmer climate, which is consistent with what was found by Mader and Madani in [13].

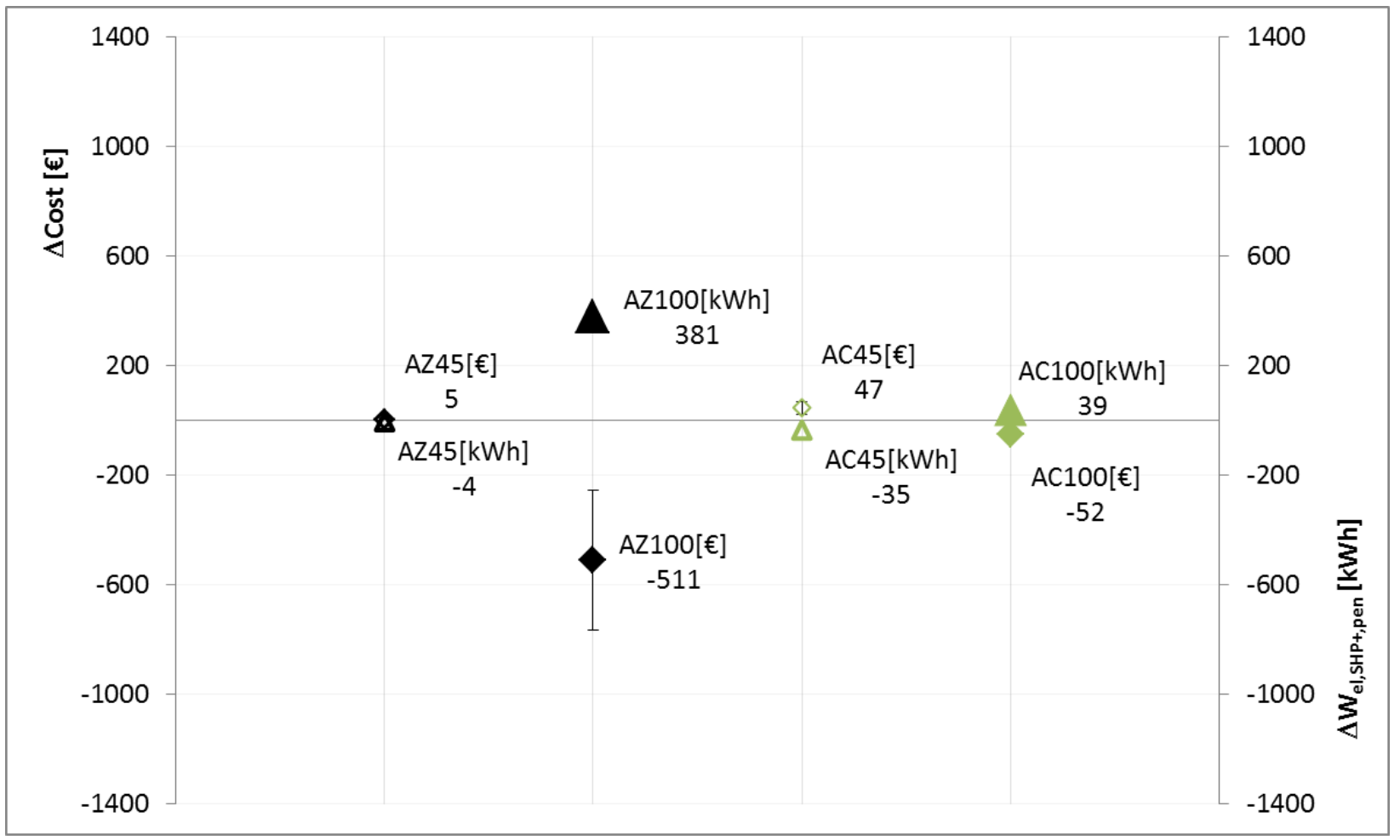

Fig. 11 Changes in system electricity $\Delta \mathrm{W}_{e l, S H P+, p e n}$ (bottom) and additional investment limit $\Delta \operatorname{Cost}_{10}$ (top) for the study of variable speed compressor. Error bars show range for electricity price of $0.1-0.3 € / \mathrm{kWh}$.

\subsection{Four/three pipe connection between heat pump and storage tank}

Fig. 12 shows the change in $\Delta \mathrm{W}_{e l, S H P+, p e n}$ (bottom) and $\Delta \operatorname{Cost}_{10}$ (top) for the study of four pipe connection. Since the reference system has a four-pipe configuration, results are interpreted as changes for the four pipe compared to the three pipe. Fig. 12 shows significant electricity savings for the configuration of four pipe connection for the combination of two buildings and climates. For the SFH45, the three pipe connection results in the water from the DHW part of the store being pushed down into the SH part during a DHW charge, resulting in unnecessary high temperatures in the $\mathrm{SH}$ part. This heat has been produced at a lower COP than in the case in the four pipe system, which operates at the SH temperatures, which are much lower than DHW temperatures for the SFH45 house with floor heating. Lower energy savings for 
the case of SFH100 house are explained by the higher operating temperatures of the heating system in the SFH100 house than in the SFH45, with a smaller temperature difference, and thus COP, between SH and DHW modes. Results, in relative differences (\%), for the case with the SFH45 are in agreement with the results of [32] despite the difference in boundary conditions and DHW profile, but not for SFH100. This shows the importance of the SH operating temperatures for the system variation.

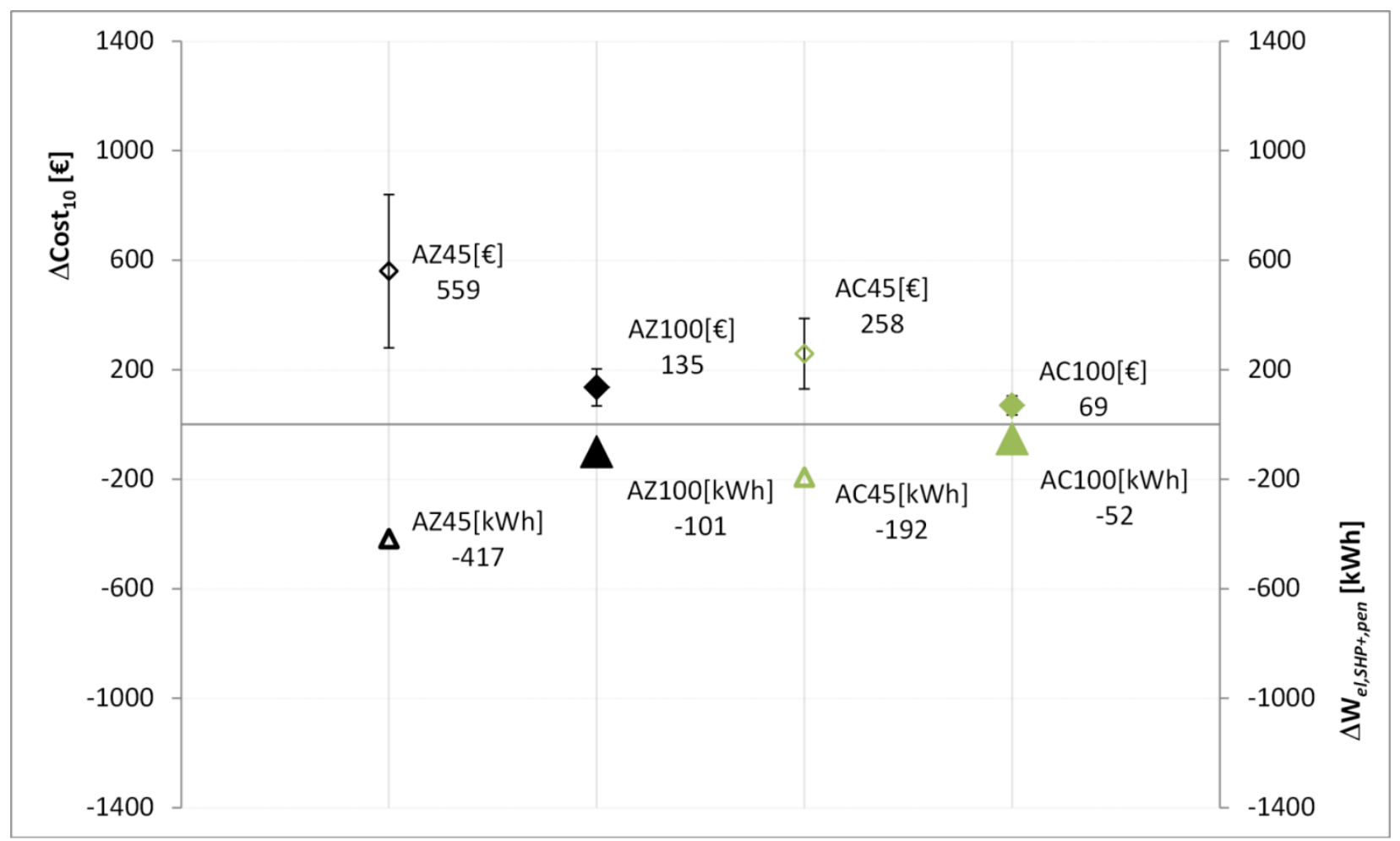

Fig. 12 Changes in system electricity $\Delta \mathrm{W}_{\text {el,SHP+,pen }}$ (bottom) and additional investment limit $\Delta$ Cost $_{10}$ (top) for the system with four pipe connections. Error bars show range for electricity price of $0.1-0.3 € / \mathrm{kWh}$

$\Delta$ Cost $_{10}$ are interpreted as cost benefit for the four pipe connection in comparison to the three pipe connection. The total range of $\Delta \operatorname{Cost}_{10}$ for both houses varies from $67 €(0.1 € / \mathrm{kWh}$ electricity price $)$ to $839 €(0.3 € / \mathrm{kWh}$ electricity price $)$ in Zurich and similarly from $35 €$ to $387 €$ in Carcassonne.

The system configuration with four pipe connection requires an extra three way-valve and an extra pipe compared to the case in the three pipe system; thus system complexity as well as cost increases slightly. The use of a four pipe system configuration is probably justified by the higher cost benefits in the SFH45 house, while the cost-effectiveness is likely to depend on economic boundaries in the SFH100 house. 


\subsection{Four way-valve in the space heating circuit}

Fig. 13 shows the change in $\Delta \mathrm{W}_{e l, S H P+, p e n}$ (bottom) and $\Delta \operatorname{Cost}_{10}$ (top) for the study of four way-valve in the space heating circuit. Changes in $\Delta \mathrm{Wel}_{\text {SHP+,pen }}$ are larger for the SFH45 house than for the SFH100 house and in Zurich more than in Carcassonne, but relative differences are similar and very small, below 2\% in all cases. Results are not as good as those shown in literature [27,30]because the potential of the use of solar for space heating is small. The systems in $[27,30]$ had a larger volume which was only heated by solar, i.e. below the volume heated by the auxiliary heater. For the system variation, the solar input to the space heating circuit is placed in the storage tank above the return line to the heat pump and this results in a use of heat pump for space heating being similar to the reference system. No optimisation on the height of inlets and outlets of the storage tank was performed.

The complexity of system variation is similar to the reference system, with a four-way valve being used instead of a three-way valve plus the addition of an extra pipe. However, the additional investment limit was shown to be small with the reference system used in the study. Significant changes in energy use and thus in cost savings are expected by optimizing the heights of pipe connections to the storage tank.

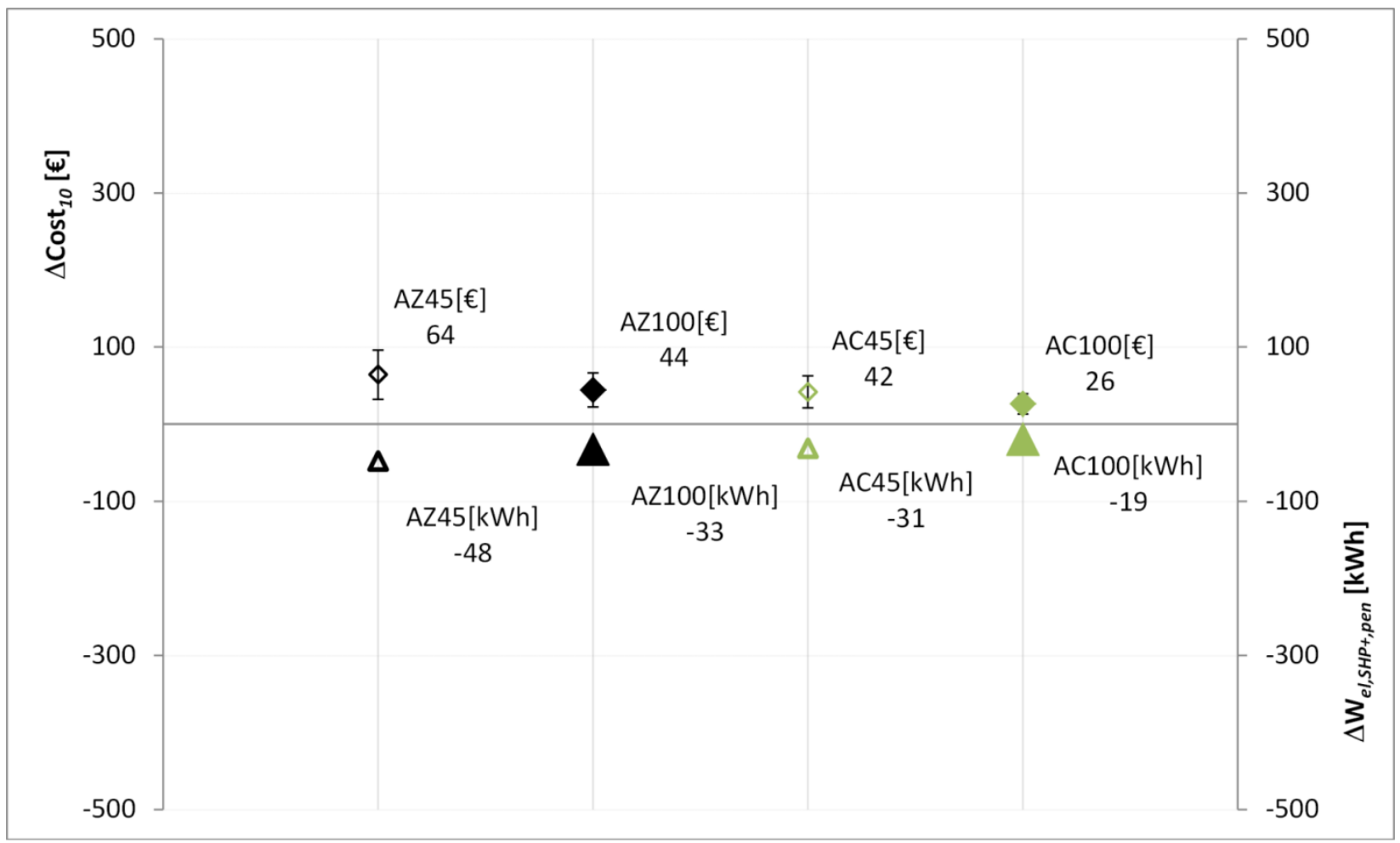

Fig. 13 Changes in system electricity $\Delta \mathrm{W}_{e l, S H P+, p e n}$ (bottom) and additional investment limit $\Delta$ Cost $_{10}$ (top) for the system with four way-valve for SH. Error bars show range for electricity price of $0.1-0.3 € / \mathrm{kWh}$ ) 
3.6. Vacuum insulation techniques on the storage tank

Fig. 14 shows the changes in $\Delta \mathrm{Wel}_{\text {SHP+,pen }}$ are bigger for the SFH100 house than for the SFH45 and in Zurich more than in Carcassonne. However, the change regarding the building is only bigger in absolute values because the electricity need is higher for the SFH100 then for the SFH45. The relative change is smaller for the SFH100 than for the SFH45. $\Delta$ Cost $_{10}$ is small to moderate for all cases, ranging from $60 €$ for SFH45 in Carcassonne with an electricity price of $0.1 € / \mathrm{kWh}$ to $276 €$ for the SFH100 house in Zurich with an electricity price of $0.3 € / \mathrm{kWh}$. (SFH45 has a higher DHW/SH ratio then the SFH100). The storage losses could be reduced for Zurich SFH45 and SFH100 by about $71 \%$ and for Carcassonne SFH45 and SFH100 by $66 \%$. This loss reduction led to a better performance of the heat pump, especially the reduced losses of the upper volume of the tank have the effect that the heat pump runs less in the DHW mode. For example, the load cycles for the SFH45 in Carcassonne could be reduced by 19\% and for the SFH45 in Zurich by over 14\% compared to the reference, which is the main cause in the reduction in $\Delta \mathrm{Wel}_{, S H P+, p e n}$. The change in heat losses have the most impact in winter time, while in summer the benefit of lower losses is small due to the fact that enough solar energy is available.

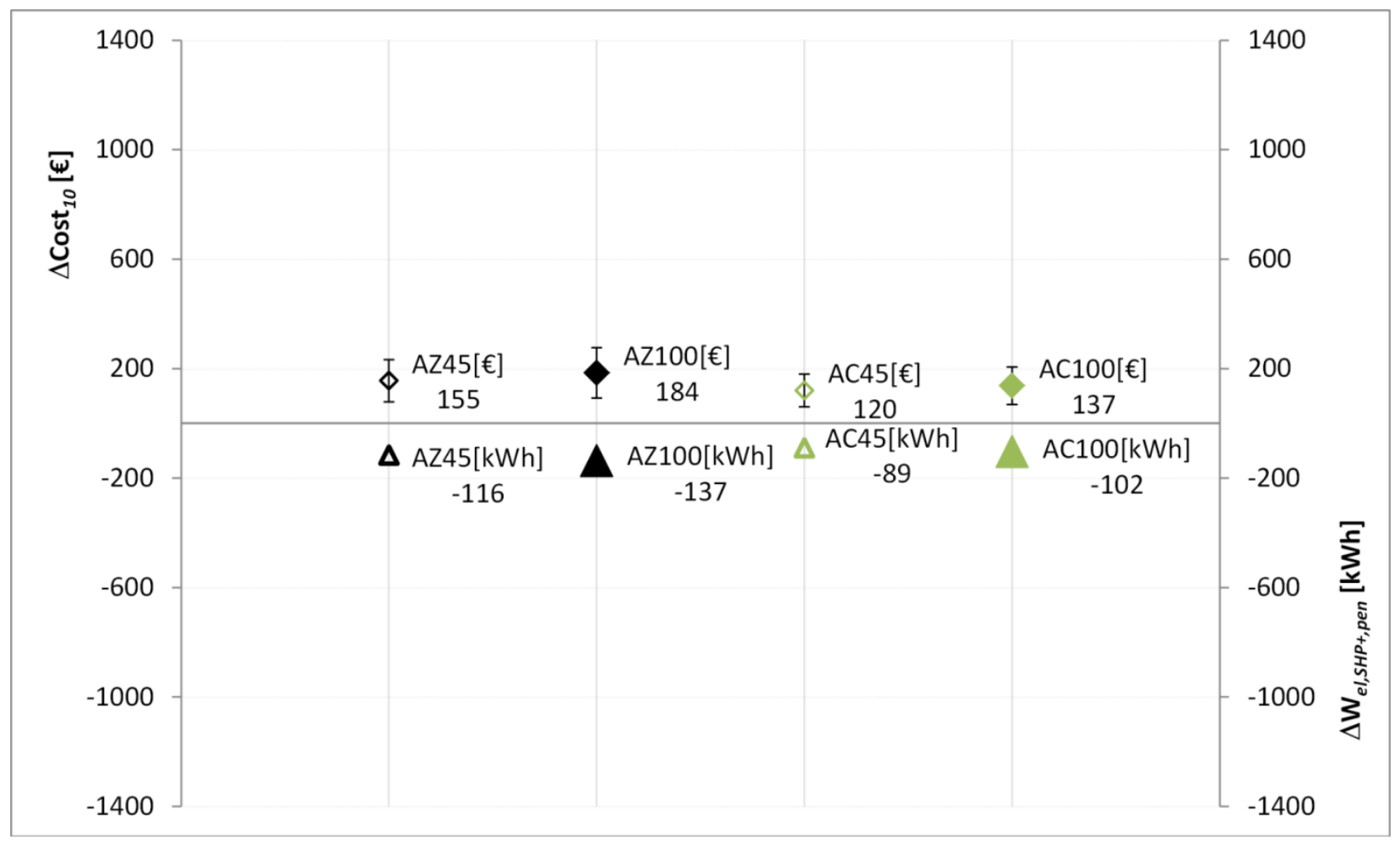

Fig. 14 Changes in system electricity $\Delta \mathrm{W}_{\mathrm{el}, \mathrm{SHP}+\text {,pen }}$ (bottom) and additional investment limit $\Delta \operatorname{Cost}_{10}$ (top) for the system with vacuum insulation. Error bars show range for electricity price of $0.1-0.3 € / \mathrm{kWh}$ 
The total range of $\Delta \mathrm{Cost10}$ for both houses varies from $78 €(0.1 € / \mathrm{kWh}$ electricity price) to $276 €(0.3$ $€ / \mathrm{kWh}$ electricity price) in Zurich and similarly from $60 €$ to $206 €$ in Carcassonne.

The complexity of the system increases due to the fact that all hydraulic components are mounted under the insulation. This leads to a more compact system with more complex design requirements of the insulation and hydraulic components positioning.

\subsection{Heat pump condenser integrated in the storage tank}

The system configuration with a condenser placed in the heat pump unit (reference) was compared to the system configuration with a condenser immersed in the storage tank. Results show that the reference system has better $\mathrm{SPF}_{S H+, p e n}$ for all combinations of the two climates and buildings. The reason is that in the reference system, the heat pump charges the DHW part of the store separately from the SH part and therefore the heat is supplied at appropriate temperature with respect to current DHW or SH energy and flow temperature demand. This separated management of the store charging is not possible with the fixed position of the condenser integrated in the tank and leads to the $\mathrm{SH}$ volume of the store having a temperature close to that for DHW use because the SH part of the store is heated at the same time as the DHW part. In addition, all heat supplied to SH goes via the store, and thus a large part is supplied indirectly by the heat pump in DHW charging mode, which operates at a lower COP than in SH mode due to higher condenser temperatures.

Fig. 15 shows the change in $\Delta \mathrm{W}_{e l, S H P+, p e n}$ (bottom) for the system variation. Results are interpreted as energy savings for the reference system. The change in $\Delta \mathrm{W}_{e l, S H P+, p e n}$ is bigger for the SFH45 house than for the SFH100 and in Zurich than in Carcassonne. The reason for this is essentially the same as for the difference between three and four pipe connection. For the SFH45 the temperature difference between SH and DHW operating temperatures is larger than for SFH100, and thus the effect of increasing the temperature of the SH part of the store to DHW charge temperature is larger for SFH45 than SFH100.

Fig. 15 shows the changes in $\Delta$ Cost $_{10}$ (top) for the system variation. Results are interpreted as maximum additional cost of the reference system in comparison to a system solution with heat pump condenser integrated in the storage tank. The total range of $\Delta$ Cost $_{10}$ varies from $51 €(0.1 € / \mathrm{kWh}$ electricity price) to $670 €(0.3 € / \mathrm{kWh}$ electricity price $)$ in Zurich and similarly from $35 €$ to $233 €$ in Carcassonne.

The system with the condenser integrated into the store is less complex than the reference system as the following components are not required: a two three-way valves and the piping between heat pump and tank. The system is also more compact, and would require less installation time, thus increasing cost savings. 


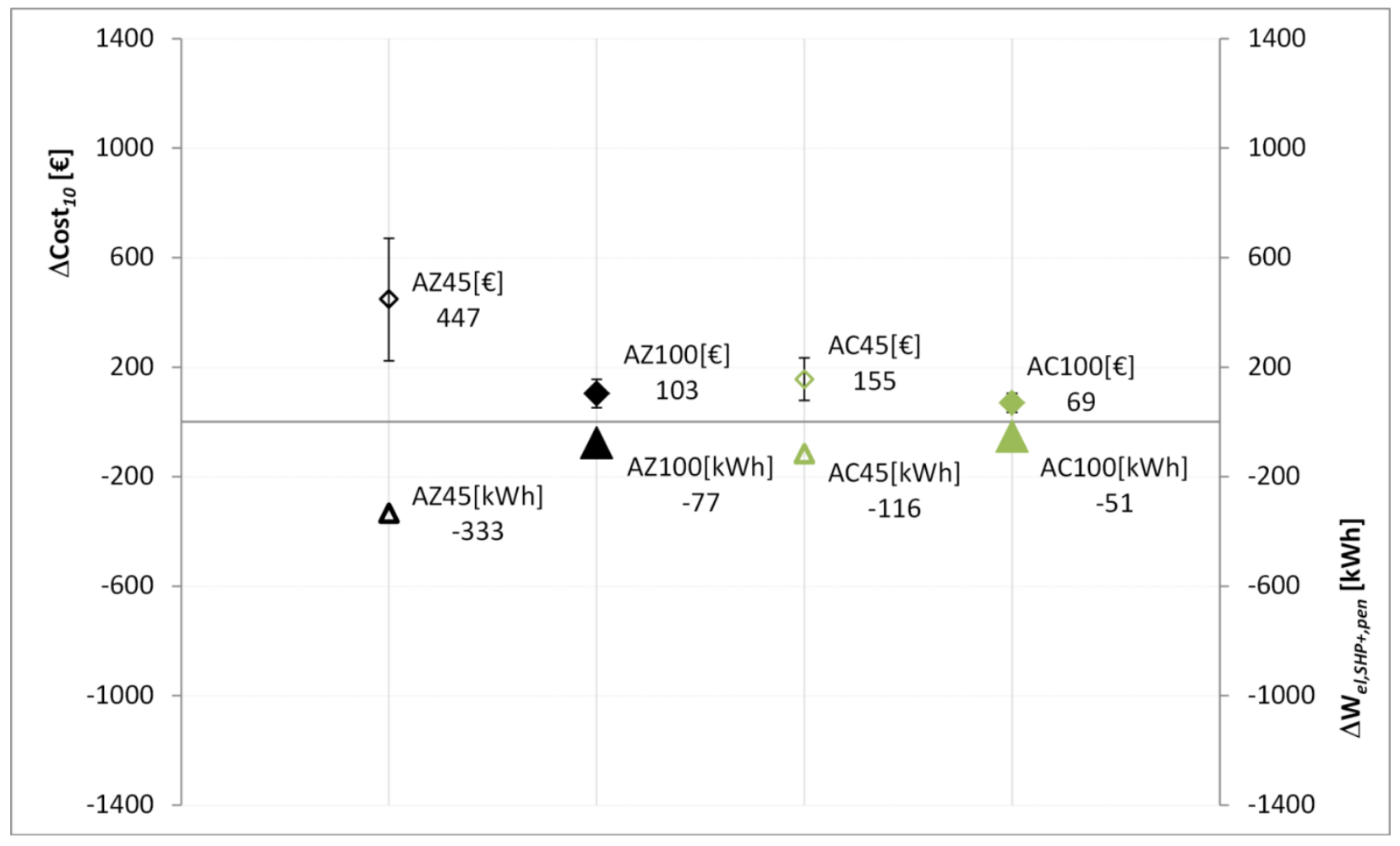

Fig. 15 Changes in system electricity $\square$ Wel,SHP+,pen (bottom) and additional investment limit $\square$ Cost10 (top) for the system with heat pump condenser integrated in the storage tank. Error bars show range for electricity price of $0.1-0.3 € / \mathrm{kWh}$

\section{Conclusions}

The present study focused on the influence of heat pump cycle, thermal storage and system integration on electricity demand in solar thermal and air source heat pump combisystems. A reference system was defined and modelled based on state of the art commercial systems for which detailed measurement data were used to derive parameters for the models. A combination of two climates, Zurich and Carcassonne, and two houses with different insulation standards (SFH45 and SFH100) was simulated. Results for the SFH45 house in Carcassonne showed an annual electricity use of $1655 \mathrm{kWh} /$ year while for the SFH100 in Zurich was $8340 \mathrm{kWh} /$ year. Several system variations were studied: vapour injection cycle for heat pump; variable speed compressor; four pipe connection between heat pump and storage tank; four-way valve in the space heating circuit; vacuum insulation technique on the storage tank and condenser integrated in the storage tank. Two key-figures were used for system comparison: the change in annual electricity use and the additional investment limit. The additional investment limit was defined as the maximum allowed 
extra investment cost, between system variation and reference, in order to have a payback time of 10 years. Thus, the additional investment cost showed the potential of a system variation for being costeffective.

Main conclusions from the study were:

- The use of an air source heat pump with vapour injection cycle led to a significant reduction in electricity demand of a solar thermal combisystem that operated at high temperature in the space heating circuit and in cold climate. This was expected and confirmed results of other studies on air source heat pump systems with no use of solar. For the house standard SFH100 in Zurich simulation results showed electricity savings of $949 \mathrm{kWh} /$ year compared to the reference solution with standard vapour compression cycle. Additional investment limit varied between $636 €$ and $1273 €$ depending on electricity price.

- A sensitivity analysis was carried out to show the impact of interest rate, inflation rate and price of electricity on the additional investment limit. Results showed that the additional investment limit was much more sensitive to the variation of electricity price than to the variation of inflation rate and annuity interest rate. Similar trend was noticed for all system variations.

- There were small differences in electricity use $(<40 \mathrm{kWh} /$ year $)$ between the system with fixed speed and with variable speed compressor, apart for the case with SHF100 house in Zurich for which the system with variable speed compressor used $381 \mathrm{kWh} / \mathrm{year}$ less electricity. This equates to an additional investment limit of $511 €$ for the variable speed compressor compared to fixed speed compressor, for the default economic parameter values. Variable speed was more attractive in colder climate than in warmer climate, which is consistent with previous studies of ASHP systems without solar.

- The system configuration with four pipe connection was better than three pipe connection and for the SFH45 house more than the SFH100. The reason was for increased electricity use in the three pipe connection is that the heat pump operates more often in DHW charging mode instead of space heating mode than in the four pipe connection, resulting in higher average operating temperatures and lower SPF. For the SFH45 the temperature difference between SH and DHW operating temperatures is larger than for SFH100, and thus the effect of increasing the temperature of the SH part of the store to DHW charge temperature is larger for SFH45 than SFH100.

- For the case with the SFH45 house in Zurich, cost benefits for the four pipe system varied between $280 €$ and $839 €$ depending on electricity price and thus a four pipe system results in 
being more cost-effective than a system with vapour injection for the specific combination of building and climate.

- The use of a four-way valve in the space heating circuit led to very small savings, less than 50 $\mathrm{kWh} /$ year for the best case scenario. This was due to the relatively small volume of the tank which was heated by solar in the reference system. This also explained why results were so poor in comparison to those from other studies. Significant changes in energy use and thus in cost savings are expected by optimizing the heights of pipe connections to the storage tank and thus there is potential for further work in this area.

- By using vacuum insulation panels, the electricity use was reduced in all combinations of the two climates and buildings, but savings were moderate. Larger electricity savings (137 kWh/year) were noticed in the case with the SFH100 house in Zurich. Additional investment limit varied between $92 €$ and $276 €$ depending on electricity price.

- As expected, the system solution with heat pump condenser integrated in the storage tank did not lead to any savings in electricity use compared to the reference solution with the condenser in the heat pump unit. For the SFH45 house in Zurich, the system with condenser integrated in the tank needs to be $670 €$ less expensive in order to be cost-effective with an electricity price of 0.3 $€ / \mathrm{kWh}$. For the other cases of climate and building, it needs to be at most $233 €$ less expensive to have a payback time of 10 years.

- The biggest difference in electricity savings was always found for Zurich rather than in Carcassonne. However, in three cases the largest savings were for the SFH45 house despite the fact that the annual electricity use is much lower than that for the SFH100 house, $3581 \mathrm{kWh} /$ year compared to $8340 \mathrm{kWh} / \mathrm{year}$. This was attributed to the fact that, in these cases, the operating level of the space heating circuit played a significant role, the SFH45 house being supplied with a $35 / 30{ }^{\circ} \mathrm{C}$ heating system while the SFH100 was supplied with a $55 / 45^{\circ} \mathrm{C}$ heating system.

Finally, the overall analysis showed that cost-effectiveness depends significantly on system boundary conditions (climates and building heating loads) and thus general conclusions are difficult to derive. While relative differences in thermal performance can be similar for different boundary conditions of climate and space heat load, due to the large variation in absolute differences in saved electricity due to different total heat demand, the key economic figure (additional investment limit) can vary considerably. For the given climates and building heating loads, the configuration with the four pipe connection is preferable for the systems that work with low operating temperature of the heating system, e.g. floor heating systems. For high temperatures of the heating system, the four pipe connection is less profitable since the system 
performs similarly to the three pipe connection, but system complexity is higher. Vapour injection cycle was shown to be interesting, especially for delivering heat at high temperature for DHW preparation or higher temperature heat distribution systems. For the use in real applications, the control of vapour refrigerant at the injection port is crucial. In this study, a perfect control was assumed. The use of variable speed compressor was shown not to be always economically justifiable. Despite that, this technology is very common and represents state of the art for systems with ASHP. Vacuum insulation techniques for insulating thermal storages have larger potential for being cost-effective in the future than now, as it is expected that more designs and products will be available in large scale and thus at more affordable price.

Within the EU/FP7 project MacSheep, several advances investigated in this study were included in the development of different solar thermal and heat pump system prototypes. Further study will demonstrate the performances of system prototypes by means of laboratory tests.

\section{Acknowledgements}

The research leading to these results has received funding from the European Union's Seventh Framework Program FP7/2007-2011 under grant agreement nº 282825 - Acronym MacSheep.

\section{References}

[1] Ruschenburg, J., Herkel, S., Henning, H.M. A statistical analysis on market-available solar thermal heat pump systems. Solar Energy, 2013; 95:79-89.

[2] Frank, E., Haller, M., Herkel, S., Ruschenburg, J. Systematic Classification of Combined Solar Thermal and Heat Pump Systems. Proc. of the EuroSun 2010 Conference, Graz, Austria.

[3] Haller, M., Frank, E. On the Potential of Using Heat from Solar Thermal Collectors for Heat Pump Evaporators. ISES Solar World Congress 2011, Kassel, Germany.

[4] European Heat Pump Association (EHPA). Outlook 2010-European Heat Pump Statistics. BrusselsBelgium.

[5] Wang, X., Yu, J., Xing, M. Performance analysis of a new ejector enhanced vapor injection heat pump cycle. Energy Conversion and Management, 2015;100:242-248. 
[6] Baek, C., Heo, J., Jung, J., Lee, E., Kim, Y. Effects of vapor injection techniques on the heating performance of a $\mathrm{CO} 2$ heat pump at low ambient temperatures. International Journal of Refrigeration, 2014;43:26-35.

[7] Redón, A., Navarro, P. E., Pitarch, M., Gonzálvez, M. J., Corberán, J.M. Analysis and optimization of subcritical two-stage vapor injection heat pump systems, Applied Energy. 2014;124:231-240.

[8] Ko, Y., Park, S., Jin, S., Kim, B., Jeong, J.H. The selection of volume ratio of two-stage rotary compressor and its effects on air-to-water heat pump with flash tank cycle. Applied Energy, 2013;104:187-196.

[9] Roh, C.W., Kim, M.S. Comparison of the heating performance of an inverter-driven heat pump system using R410A vapor-injection into accumulator and compressor. International Journal of Refrigeration, 2012;35:434-444.

[10] Heo, J., Jeong, M.W., Baek, C., Kim, Y. Comparison of the heating performance of air-source heat pumps using various types of refrigerant injection. International Journal of Refrigeration, 2011;34:444453.

[11] Del Col, D., Azzolin, M., Benassi, G., Mantovan, M. Energy efficiency in a ground source heat pump with variable speed drives. Energy and Buildings, 2015;91:105-114.

[12] Safa, A. A., Fung, A. S., Kumar, R. Performance of two-stage variable capacity air source heat pump: Field performance results and TRNSYS simulation. Energy and Buildings, 2015;94:80-90.

[13] Mader, G., Madani, H. Capacity control in air-water heat pumps: Total cost of ownership analysis. Energy and Buildings, 2014;81:296-304.

[14] Madani, H., Claesson, J., Lundqvist, P. Capacity control in ground source heat pump systems: Part I: modeling and simulation. International Journal of Refrigeration, 2011;34:1338-1347.

[15] Madani, H., Claesson, J., Lundqvist, P. Capacity control in ground source heat pump systems part II: Comparative analysis between on/off controlled and variable capacity systems. International Journal of Refrigeration, 2011;34:1934-1942.

[16] Lee, C. K. Dynamic performance of ground-source heat pumps fitted with frequency inverters for part-load control. Applied Energy, 2010;87:3507-3513.

[17] Cuevas, C., Lebrun, J. Testing and modelling of a variable speed scroll compressor. Applied Thermal Engineering, 2009;29:469-478. 
[18] Karlsson, F., Fahlén, P. Capacity-controlled ground source heat pumps in hydronic heating systems. International Journal of Refrigeration, 2007;30:221-229.

[19] Phillips, W. F., Dave, R.N. Effects of Stratification on the Performance of Liquid-Based Solar Heating-Systems. Solar Energy,1982;29(2):111-120.

[20] Lavan, Z., Thompson, J. Experimental Study of Thermally Stratified Hot Water Storage Tanks. Solar Energy, 1977;19(5), 519-524.

[21] Andersen, E., Furbo, S., Fan, J. Multilayer fabric stratification pipes for solar tanks. Solar Energy, 2007;81:1219-1226.

[22] Furbo,S., Andersen, E., Thür, A., Jivan S. L., Andersen, K. D. Performance improvement by discharge from different levels in solar storage tanks. Solar Energy, 2005;79(5), 431-439.

[23] Andersen, E., Jordan, U., Shah, L.J., Furbo, S. Investigation of the Solvis stratification inlet pipe for solar tanks. Proc. of the EuroSun 2004 Conference, Freiburg, Germany.

[24] Knudsen, S., Furbo, S. Thermal stratification in vertical mantle heat-exchangers with application to solar domestic hot-water systems. Applied Energy, 2004;78(3), 257-272.

[25] Bales, C., Persson, T. External DHW units for solar combisystems. Solar Energy, 2003;74, 193-204.

[26] Davidson, J.H., Adams, D.A. Fabric Stratification Manifolds for Solar Water-Heating. Journal of Solar Energy Engineering, 1994;116(3), 130-136.

[27] Glembin, J., Rockendorf, G. Simulation and evaluation of stratified discharging and charging devices in combined solar thermal systems. Solar Energy, 2012;86:407-420.

[28] Haller, M.Y. Combined solar and pellet heating systems- Improvement of energy efficiency by advanced heat storage techniques, hydraulics, and control: Ph.D. thesis, 2010.

[29] Thür, A. Compact solar combisystem: Ph. D. thesis, report R-160, Department of Civil Engineering, Technical University of Denmark, 2007.

[30] Lorenz K, Bales C, Persson T. Evaluation of solar thermal combisystems for the Swedish climate. Proc. of the Eurosun 2000 conference, Copenaghen, Denmark.

[31] Haller, M., Haberl, R., Mojic, I., Frank, E. Hydraulic integration and control of heat pump and combi-storage: Same components, big differences. Energy Procedia, 2014; 48:571-580.

[32] Poppi, S., Bales, C. Influence of Hydraulics and Control of Thermal Storage in Solar Assisted Heat Pump Combisystems. Energy Procedia, 2014;48:946-955. 
[33] Kalnæs, S.E., Jelle, B.P. Vacuum insulation panel products: A state-of-the-art review and future research pathways. Applied Energy, 2014;116:355-375

[34] Fuchs B, Hofbeck K, Faulstich M. Vacuum insulation panels - A promising solution for high insulated tanks. Energy Procedia, 2012;30:424-427.

[35] Fernández-Seara, J., Piñeiro, C., Dopazo, J. A., Fernandes, F. S. Experimental analysis of a direct expansion solar assisted heat pump with integral storage tank for domestic water heating under zero solar radiation conditions. Energy Conversion and Management, 2012;59:1-8.

[36] Chaiwongsa, P., Duangthongsuk, W. Hot Water Making Potential Using of a Conventional AirConditioner as an Air-Water Heat Pump. Procedia Engineering, 2011;8:165-170.

[37] Guo, J.J., Wu, J.Y., Wang, R.Z, Li, S. Experimental research and operation optimization of an airsource heat pump water heater. Applied Energy, 2011;88:4128-4138.

[38] Han, Y.M, Wang, R.Z., Dai, Y.J. Thermal stratification within the water tank. Renewable and Sustainable Energy Reviews, 2009; 13(5):1014-1026.

[39] Zhang, J., Wang, R.Z., Wu, J.Y. System optimization and experimental research on air source heat pump water heater. Applied Thermal Engineering, 2007;27:1029-1035.

[40] Colclough, S., McGrath, T. Net energy analysis of a solar combisystem with Seasonal Thermal Energy Store. Applied Energy. 2015;147:611-6

[41] Asaee, S.R., Ugursal, V.I., Beausoleil-Morrison, I., Ben-Abdallah, N. Preliminary study for solar combisystem potential in Canadian houses. Applied Energy. 2014;130:510-8

[42] Sterling, S.J., Collins, M.R. Feasibility analysis of an indirect heat pump assisted solar domestic hot water system. Applied Energy. 2012;93:11-7

[43] Weiss, Werner W. Solar heating systems for houses: a design handbook for solar combisystems. Earthscan, 2003[44] Fuller, S. Life-cycle cost analysis (LCCA). National Institute of Building Sciences, An Authoritative Source of Innovative Solutions for the Built Environment. 2010;1090.

[45] Colclough, S., Griffiths, P. Financial analysis of an installed small scale seasonal thermal energy store, Renewable Energy, 2016; 86: 422-428.

[46] Chaturvedi, S.K., Gagrani, V.D., Abdel-Salam, T.M. Solar-assisted heat pump - A sustainable system for low-temperature water heating applications. Energy Conversion and Management, 2014;77: $550-557$. 
[47] Hin, J.N.C., Zmeureanu, R. Optimization of a residential solar combisystem for minimum life cycle cost, energy use and exergy destroyed. Solar Energy, 2014;100:102-113.

[48] Hin, J.N.C. Life cycle optimization of a residential solar combisystem for minimum cost, energy use and exergy destroyed. M.Sc. thesis, Concordia University, Canada; 2013.

[49] Leckner, M., Zmeureanu, R. Life cycle cost and energy analysis of a Net Zero Energy House with solar combisystem. Applied Energy, 2011;88:232-241.

[50] MacSheep. MacSheep - New Materials and Control for a next generation of compact combined Solar and heat pump systems with boosted energetic and exergetic performance, European Union's Seventh Framework Programme project, 2012-2015. (http://www.macsheep.spf.ch/) accessed on 2015-03-09.

[51] Klein, A., Beckman, A., Mitchell, W., Duffie, A., 2011 TRNSYS 17-a transient system simulation program. Madison. Solar Energy Laboratory, University of Wisconsin.

[52] Hadorn, J. C. Solar and Heat Pump Systems for Residential Buildings. Wiley; 2015.

[53] Dott, R., Haller, M., Ruschenburg, J., Ochs, F., Bony,J. The Reference Framework for System Simulations of the IEA SHC Task 44 / HPP Annex 38 - Part B: Buildings and Space Heat Load - A techinical report of subtask C, Report C1 Part B, Paris. (http://task44.ieashc.org/data/sites/1/publications/T44A38_Rep_C1_B_ReferenceBuildingDescription_Final_Revised_130 906.pdf ) accessed on 2015-05-25.

[54] Kuhn, T.E., Fath, K., Bales, C., Gustafsson, M., Nouvel, R., Fedrizzi, R. Development of Systemic Packages for Deep Energy Renovation of Residential and Tertiary Buildings including Envelope and Systems - Deliverable 2.3 - iNSPiRe project report. (http://www.inspirefp7.eu/wpcontent/uploads/2015/01/WP2_D2.3_20141118_P5_RES-Availability-Survey-and-Boundary-Conditionsfor-Simulations_WEBSITE.pdf) accessed on 2016-01-29

[55] Bales, C., Betak, J., Broum, M., Chèze, D., Cuvillier, G., Haberl, R., Hafner, B., Haller, M., Hamp, Q., Heinz, A., Hengel, F., Kruck, A., Matuska, T., Mojic,I., Petrak, J., Poppi, S., Sedlar, J., Sourek, B., Thissen, B., Weidinger, A., 2015. Optimized solar and heat pump systems, components and dimensioning - Deliverable 7.3 - MacSheep report. (http://www.macsheep.spf.ch/Reports-Deliverables.245.0.html2015) accessed on 2015-03-09.

[56] EURSOTAT, Electricity prices for domestic consumers - bi-annual data (from 2007 onwards. (http://appsso.eurostat.ec.europa.eu/nui/show.do?dataset=nrg_pc_204\&lang=en) accessed on 2015-05-10. 
[57] Eicker,U., Colmenar-Santos, A., Teran, L., Cotrado, M., Borge-Diez, D. Economic evaluation of solar thermal and photovoltaic cooling systems through simulation in different climatic conditions: An analysis in three different cities in Europe. Energy and Buildings, 2014;70: 207-223.

[58] Axaopoulos, P. J., Fylladitakis, E. D. Performance and economic evaluation of a hybrid photovoltaic/thermal solar system for residential applications. Energy and Buildings, 2013;65:488-496.

[59] Agrawal, B., Tiwari, G.N. Life cycle cost assessment of building integrated photovoltaic thermal (BIPVT) systems. Energy and Buildings, 2010; 42(9);1472-1481.

[60] Kalogirou,S. Thermal performance, economic and environmental life cycle analysis of thermosiphon solar water heaters. Solar Energy, 2009;83(1):39-48.

[61] Andersen, E., Shah, L.J., Furbo, S. Thermal Performance of Danish Solar Combi Systems in Practice and in Theory. Journal of solar energy engineering. 2004;126:744-749.

[62] Kaçan, E. Exergetic optimization of basic system components for maximizing exergetic efficiency of solar combisystems by using response surface methodology. Energy and Buildings, 2015; 91: 65-82.

[63] Data set for Viessmann Vitosol 200F, Planungsanleitung, A. Viessamann Deutschland GmbH, Germany, 2011.

(http://www.viessmann.de/de/ein-_zweifamilienhaus/produkte/Solarthermie/Vitosol_200-F.html) Data accessed on 2015-03-09.

[64] Data set for Viessmann Vitocell 340-M/360-M , Datenblatt, A. Viessamann Deutschland GmbH, Germany, 2013.

(http://www.viessmann.de/content/dam/internet-global/pdf_documents/Datenblaetter_2013/WWB/DB5368782_05-2013.pdf ) Data accessed on 2015-03-09.

[65] EN 12977-3:2008. Thermal solar systems and components. Custom built systems Performance test methods for solar water heater stores.

[66] Technical guide for Viessmann Vitocal 200-S, A. Viessamann Deutschland GmbH, Germany, 2010. (http://www.viessmann.de/content/dam/internet-

global/pdf_documents/Datenblaetter_2013/EV/5811525_05-2013_DE.pdf ) Data accessed on 2015-03-09.

[67] Haller, Y. M., Perers, B., Bales, C., Paavilainen, J., Dalibard, A., Fischer, S., Bertram, E. TRNSYS Type 832 v5. 00 „Dynamic Collector Model by Bengt Perers “: Updated Input-Output Reference. 2012.

[68] Drück, H., Pauschinger, T., 2006. MULTIPORT Store-Model Type 340. 
[69] Haller, M.Y., Mojic, I., Frank, E., Kaufmann, M., Lötscher, L., Podhradsky, J., Huggenberger, A., Boller, S., Meier, B. Disturbance of stratification caused by direct horizontal inlets into a water storage tank. Proc. of the EuroSun 2014 Conference, Aix-les-Bains, France.

[70] Heinz, A., Haller, Y. M., Appendix A3-Description of TRNSYS Type 877 by IWT and SPF. Models of Sub-Components and Validation for the IEA SHC Task, 2012.

[71] prEN 12977-2:2007. Thermal Solar Systems and Components - Custom Built Systems - Part 2: Test methods for solar water heaters and combisystems.

[72] Hengel, F., Heinz, A., Rieberer, R. Analysis of an air source heat pump system with speed controlled compressor and vapor injection. Proc. of the IEA Heat Pump Conference 2014, Montreal, Canada [73] Nordlander, S. TRNSYS Type 221 "Four way valve”. 2007. SERC, Högskolan Dalarna,Sweden.

[74] Product Data Sheet for va-Q-plus, va-Q-tec AG, Germany, 2015.

(http://www.va-q-tec.com/en/download-center/download.html?pid=371\&aid=385) Data accessed on 2016-01-26.

[75] Poppi, S., Bales, C., Haller, M. Y., Heinz, A. Influence of boundary conditions and component size on electricity demand in solar thermal and heat pump combisystems. Applied Energy. 2016; 162: 1062-73 